\title{
ATIC as a link between antirheumatic drugs and regulation of energy metabolism in skeletal muscle
}

\author{
KLEMEN DOLINAR ${ }^{1}$ \\ ALEXANDER V. CHIBALIN ${ }^{2,3}$ \\ SERGEJ PIRKMAJER ${ }^{1, *}$ \\ ${ }^{1}$ University of Ljubljana, Faculty of Medicine, \\ Institute of Pathophysiology, Ljubljana, Slovenia \\ ${ }^{2}$ Karolinska Institutet, Department of Molecular \\ Medicine and Surgery, Integrative Physiology, \\ Stockholm, Sweden \\ ${ }^{3}$ National Research Tomsk State University, Tomsk, \\ Russia \\ *Correspondence: \\ Sergej Pirkmajer \\ E-mail: sergej.pirkmajer@mf.uni-lj.si
}

Keywords: rheumatic diseases; diabetes; methotrexate; antirheumatic drugs; ATIC; ZMP; AMPK; skeletal muscle

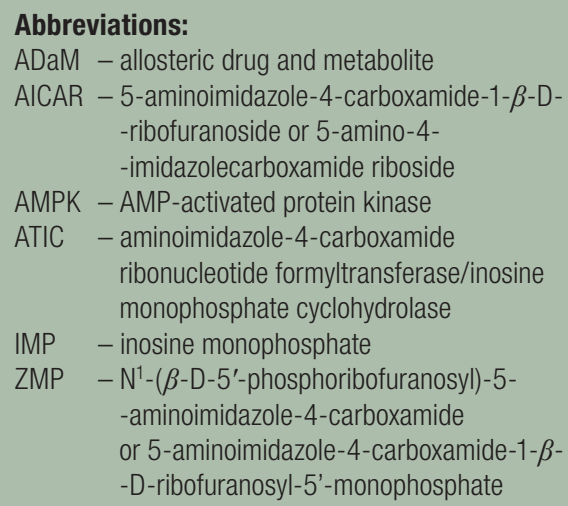

Received April 27, 2020

Revised June 18, 2020

Accepted July 7, 2020

\begin{abstract}
Chronic inflammatory rheumatic diseases, such as rheumatoid arthritis, psoriatic arthritis, and systemic lupus erythematosus, increase the risk of developing insulin resistance, metabolic syndrome, andlor type 2 diabetes. While inflammation is thought to be a major mechanism underlying metabolic dysregulation in rheumatic diseases, antirheumatic drugs that exert direct metabolic effects in addition to suppressing inflammation, might be particularly useful to prevent metabolic complications. Here we review antirheumatic drugs, such as methotrexate, that inhibit ATIC, the final enzyme in the de novo purine biosynthesis, responsible for conversion of $Z M P$ to IMP. Inhibition of ATIC results in accumulation of $Z M P$, thus promoting activation of AMP-activated protein kinase (AMPK), a major regulator of cellular energy metabolism and one of the most promising targets for the treatment of insulin resistance and type 2 diabetes. We focus especially on ATIC inhibition and AMPK activation in skeletal muscle as this is the largest and one of the most metabolically active tissues with a major role in glucose homeostasis. As an important site of insulin resistance, skeletal muscle is also one of the main target tissues for pharmacological therapy of type 2 diabetes. Finally, we review the metabolic effects of ATIC-inhibiting antirheumatic drugs and discuss whether these drugs might improve systemic glucose homeostasis by inhibiting ATIC and activating AMPK in skeletal muscle.
\end{abstract}

\section{INTRODUCTION}

$\mathrm{T}$ ype 2 diabetes and cardiovascular diseases are highly prevalent and 1 present a major public health challenge (1). Chronic inflammatory rheumatic diseases, such as rheumatoid arthritis, psoriatic arthritis, and systemic lupus erythematosus, increase the risk of insulin resistance (2), type 2 diabetes (3), the metabolic syndrome (4, 5), and/or cardiovascular complications (6). Antirheumatic drugs suppress inflammation, but they are not all equally effective at reducing the risk of developing diabetes $(7,8)$ or cardiovascular events $(9)$. Some potent immunosuppressive and anti-inflammatory drugs, such as glucocorticoids or calcineurin inhibitors, may even increase the risk of metabolic dysregulation $(8,10$, 11). Given the high prevalence of metabolic as well as rheumatic diseases, drugs that help to maintain metabolic homeostasis and reduce the risk of metabolic complications would be particularly beneficial.

Skeletal muscle accounts for $-40 \%$ of body weight and $20-30 \%$ of basal oxygen consumption and is the largest metabolic tissue under the physiological conditions (12). In type 2 diabetes, insulin resistance impairs insulin-stimulated glucose uptake and glycogen storage in skeletal muscle, thereby contributing to development of hyperglycaemia (13-15). 
Pharmacological agents that decrease insulin resistance and/or stimulate glucose uptake independently of insulin would therefore be useful for treatment of type 2 diabetes. In this respect, activation of AMP-activated protein kinase (AMPK) is one of the most promising strategies to improve metabolic dysregulation in skeletal muscle (1618). Activation of AMPK enhances insulin action and stimulates insulin-independent glucose uptake in skeletal muscle, thus improving metabolic homeostasis and opposing development of type 2 diabetes (19,20,21,22, 23, 24). However, most experimental AMPK activators that have been discovered or developed so far do not efficiently target AMPK isoforms which are expressed in skeletal muscle (25-27) or have poor pharmacokinetic properties (28), highlighting the need for new approaches towards AMPK activation in skeletal muscle.

Interestingly, several antirheumatic drugs, including salicylate and methotrexate, have been shown to promote activation of AMPK (29-31). On the other hand, both drugs were shown to be inhibitors of 5-aminoimidazole4-carboxamide ribonucleotide formyltransferase/inosine monophosphate (IMP) cyclohydrolase (ATIC) (32-35), which is recognized as a promising target in development of new antidiabetic compounds $(30,36)$. Anticancer drug pemetrexed, a compound related to methotrexate, also inhibits ATIC and activates AMPK (37), but it is not used for treatment of rheumatic diseases and will not be discussed here. Here, we will review the evidence whether antirheumatic drugs might promote metabolic homeostasis in skeletal muscle by inhibiting ATIC.

\section{AMPK as a pharmacological target in skeletal muscle}

AMPK is a major cellular energy sensor and regulator of cellular metabolism (38-41). AMPK is a heterotrimeric serine-threonine kinase comprising the catalytic $\alpha$ (isoforms $\alpha 1$ and $\alpha 2$ ) and the regulatory $\beta$ (isoforms $\beta 1$ and $\beta 2$ ) and $\gamma$ (isoforms $\gamma 1-3$ ) subunits $(41,42)$. AMPK senses cellular energy status primarily by monitoring changes in the AMP:ATP ratio $(41,43)$, although changes in the ADP:ATP ratio also contribute (44). Both AMP and ADP bind to the $\gamma$ subunit and activate AMPK by promoting phosphorylation of AMPK $\alpha$ Thr172. In addition, AMP, but not ADP, also causes allosteric activation of AMPK $(40,44-46)$. AMPK can also be activated independently of changes in adenine nucleotides (47) by an increase in cytoplasmic $\mathrm{Ca}^{2+}(48-50)$ or by a decrease in intracellular glucose concentration $(51,52)$.

Numerous pharmacological activators of AMPK have emerged in the last three decades (reviewed in detail in (18)). Based on their mechanism of action, they can be divided into three major groups (Table 1). The first group comprises direct activators that bind to or close to the AMP-binding site. The prototypical representative of this group is AICAR (5-aminoimidazole-4-carboxamide-1- $\beta$ -
D-ribofuranoside or 5-amino-4-imidazolecarboxamide riboside), an adenosine analogue and the oldest and the most widely used experimental AMPK activator. AICAR is actually a prodrug that is intracellularly phosphorylated to ZMP (5-aminoimidazole-4-carboxamide-1- $\beta$-D-ribofuranosyl-5'-monophosphate), which directly binds to AMPK and activates it (53) (see below: Intracellular metabolism of AICAR and ZMP). ZMP binds to the AMPbinding sites on the $\gamma$ subunit (54) and this is required for its ability to activate AMPK (47). C2 is another pharmacological compound that binds to the $\gamma$ subunit and activates AMPK (Table 1) (55); however, it does not bind to the nucleotide-binding sites but next to them (56).

To avoid ambiguity, it has to be stressed that different nomenclatures are in use for AICAR (a nucleoside) and ZMP (a nucleotide). Indeed, confusingly, different research fields have adopted different nomenclatures. Thus, AICAR is sometimes used to denote the nucleotide form ZMP (57-63). However, in the vast majority of research literature on AMPK, the term AICAR (aka Acadesine) (64) refers to the non-phosphorylated precursor (nucleoside) of ZMP $(16,18,53)$. ZMP $(65,66)$ has also been referred to as AICAR-monophosphate $(37,67)$, AICAribotide (68, 69), Acadesine 5'-monophosphate (64), as well as a Z-nucleotide $(66,70)$. Correspondingly, AICAR can be referred to as Z-nucleoside, Z-riboside, and AICAriboside $(28,59,61,63,66,69)$. The letter $Z$ denotes 5-amino-4-imidazolecarboxamide (AICA, Z-base) based on the nomenclature for 5-amino-4-imidazolecarboxamide (Z) nucleotides established in 1980s (65, 66, 70). Here we will follow the convention of the AMPK field and we will strictly use ZMP for the nucleotide and AICAR for the corresponding nucleoside.

The second group of AMPK activators comprises direct activators that bind outside the AMP-binding sites (Table 1), such as A-769662 (25, 71) and salicylate (31). AICAR (as ZMP), A-769662, and salicylate activate AMPK allosterically and by stimulating phosphorylation and/or inhibiting dephosphorylation of Thr172 $(25,31$, $41,47,53,72)$. However, while ZMP binds to the AMPbinding sites on the $\gamma$ subunit (54), A-769662 and salicylate bind to a specific pocket between the $\alpha$ and $\beta$ subunits termed the allosteric drug and metabolite (ADaM) site (73). Other compounds that activate AMPK by binding to this site include MK-8722 (74) and PF-739 (75) (Table 1).

The third group comprises indirect activators, which activate AMPK by inhibiting energy metabolism or by increasing intracellular $\mathrm{Ca}^{2+}$ concentrations (Table 1). Inhibitors of energy metabolism increase the AMP:ATP ratio, which results in AMP-stimulated AMPK activation via the $\gamma$ subunit (47). An increase in the AMP:ATP ratio underlies or at least contributes to AMPK activation by anti-diabetic drugs metformin and canagliflozin, which inhibit complex I of the respiratory chain (76-80), as well 
Table 1. Direct and indirect pharmacological AMPK activators. ADaM site: allosteric drug and metabolite site.

\begin{tabular}{|c|c|c|c|}
\hline Group & Pharmacological activator & Chemical structure & Site of action (comments) \\
\hline \multirow{2}{*}{$\begin{array}{l}\text { Direct activators that } \\
\text { bind to or close to the } \\
\text { AMP-binding site }\end{array}$} & AICAR & & AMPK: AMP-binding site \\
\hline & $\mathrm{C} 2$ & & AMPK: close to the AMP-binding site \\
\hline \multirow{4}{*}{$\begin{array}{l}\text { Direct activators that } \\
\text { bind outside the } \\
\text { AMP-binding site }\end{array}$} & A-769662 & & AMPK: ADaM site \\
\hline & Salicylate & & AMPK: ADaM site \\
\hline & MK-8722 & & AMPK: ADaM site \\
\hline & PF-739 & & AMPK: ADaM site \\
\hline \multirow{5}{*}{ Indirect activators } & Metformin & & $\begin{array}{l}\text { Mitochondria (inhibits mitochondrial } \\
\text { respiration and increases the AMP:ATP ratio) }\end{array}$ \\
\hline & Canagliflozin & & $\begin{array}{l}\text { Mitochondria (inhibits mitochondrial } \\
\text { respiration and increases the AMP:ATP ratio) }\end{array}$ \\
\hline & 2-deoxyglucose & & $\begin{array}{l}\text { Glycolysis (inhibits glycolysis and increases } \\
\text { the AMP:ATP ratio) }\end{array}$ \\
\hline & Dinitrophenol & & $\begin{array}{l}\text { Mitochondria (uncouples mitochondria and } \\
\text { increases the AMP:ATP ratio) }\end{array}$ \\
\hline & A23187 & & $\begin{array}{l}\text { Plasma and organelle membranes (increases } \\
\text { intracellular }[\mathrm{Ca} 2+] \text { ) }\end{array}$ \\
\hline
\end{tabular}


as experimental compounds, such as 2-deoxyglucose, which inhibits glycolysis, and dinitrophenol, which uncouples mitochondria (47). Other indirect AMPK activators, such as $\mathrm{Ca}^{2+}$ ionophore A23187, increase intracellular $\mathrm{Ca}^{2+}$ concentrations, thus leading to AMPK activation via $\mathrm{Ca}^{2+} /$ calmodulin-dependent protein kinase kinase 2 (47-50). Some compounds act by more than one mechanism. For instance, salicylate is a direct AMPK activator (31) as well as a mitochondrial uncoupler (81) and inhibitor of ATIC (32).

Once activated, AMPK stimulates ATP-generating catabolic processes and inhibits ATP-consuming anabolic processes $(38,41)$. In rat skeletal muscles, activation of AMPK with AICAR increases glucose uptake and fatty acid oxidation $(19,82-84)$. However, it should be noted that effects of AICAR depend on the nutritional state as well as muscle (fibre) type, AICAR being less effective AMPK activator in oxidative than glycolytic muscles $(22,83,85)$. Activation of AMPK and increase in glucose uptake after treatment with AICAR have also been observed in skeletal muscles of insulin-resistant obese rats (86) and human subjects with type 2 diabetes (87). Further, AICAR suppresses endogenous glucose production and decreases plasma triglycerides and fatty acids in insulin-resistant obese rats (86). Similarly, administration of AICAR in subjects with type 2 diabetes reduces hepatic glucose output and suppresses lipolysis, thus reducing plasma glucose and free fatty acid concentrations (88). However, beneficial effects on glucose homeostasis were not paralleled by improvements in lipid profile in all experimental models (89). Finally, activation of AMPK probably underlies increased insulin sensitivity after muscle contraction or exercise (90). Taken together, these and many other studies (19-24) suggest that pharmacological activators of AMPK could be used in the fight against insulin resistance and type 2 diabetes $(16,17)$.

Most experimental AMPK activators have one or more shortcomings that prevent them from being used as clinical treatments for insulin resistance and type 2 diabetes (91). For example, AICAR has off-target effects, including modulation of other AMP-sensitive enzymes, such as fructose-1,6-bisphosphatase (92) and glycogen phosphorylase (93), and poor oral bioavailability (28). Notably, human studies demonstrated that even intravenous infusion of AICAR results in plasma concentrations $(-0.16-$ $0.18 \mathrm{mM}$ ) that are below the threshold for activation of AMPK in skeletal muscle $(88,94)$. A-769662 also shows poor oral bioavailability (71) as well as off-target effects, notably inhibition of $\mathrm{Na}^{+} / \mathrm{K}^{+}$-ATPase (95). Finally, A-769662 and several other AMPK activators that bind to the $\mathrm{ADaM}$ site, preferentially activate the $\beta 1$-containing AMPK complexes $(18,25)$. This makes them less effective AMPK activators in tissues that express predominantly the $\beta 2$-containing AMPK complexes (75), which includes skeletal muscle $(26,27)$.

\section{Intracellular metabolism of AICAR and ZMP}

As well as a pharmacological AMPK activator, AICAR is an endogenous purine precursor of ZMP $(61,96-101)$. AICAR enters the cell via nucleoside transporters (102105) and is converted to ZMP (AICAR-monophosphate) by adenosine kinase $(53,66)$. As well as from AICAR, ZMP can be synthesized from AICA, an adenine analogue $(37,70,106)$. Following uptake into the cell, AICA is converted to ZMP in the reaction catalysed by adenine phosphoribosyltransferase (APRTase), thus mimicking conversion of adenine to the AMP in the salvage pathway of purine synthesis $(37,70)$.

Once ZMP is formed, it likely has four possible fates. First, it can be phosphorylated to ZDP and/or ZTP (61, 66, 107, 108). Second, ZMP can be dephosphorylated back to AICAR in a reaction catalysed by 5 '-nucleotidase $(61,107)$. AICA $(109)$ and AICAR $(96,97,99)$ are measurable in urine, indicating that dephosphorylation of ZMP is important under physiological conditions. Third, some evidence suggests that ZMP can be converted back to $\mathrm{N}$-succinyl-5-aminoimidazole-4-carboxamide ribonucleotide (SAICAR or sZMP) by adenylosuccinate lyase (66). Finally, ZMP can be converted to IMP by ATIC in the last two steps of the de novo purine synthesis pathway (Figure 1).

\section{The physiological role of ATIC}

ATIC, encoded by the $A T I C$ gene (also known as the PURH gene), is a bifunctional enzyme responsible for the catalysis of the last two steps in the de novo purine biosynthesis, i.e. conversion of ZMP to IMP. ZMP is first formylated to formyl-AICAR (FAICAR) by AICAR formyltransferase (AICARFT) which uses $\mathrm{N}^{10}$-formyl tetrahydrofolate (10-CHO-THF) as the formyl donor and then FAICAR is converted to IMP by IMP cyclohydrolase (IMPCH; also known as inosinicase) $(110,111)$.

ATIC was first isolated by Flaks et al. in 1957 from chicken (110). In 1991, Ni et al. cloned and sequenced chicken ATIC cDNA, which was the first eukaryotic ATIC cDNA to be cloned (112). Human ATIC cDNA was cloned and sequenced a few years later (113-115). Cloning of ATIC cDNA enabled the use of the site-directed mutagenesis and production of large quantities of easily purifiable recombinant ATIC protein in bacterial expression systems, which opened the door for mechanistic and structural studies. Chicken ATIC was also the first ATIC with a determined protein structure. The structure was determined by Greasley et al. in 2001 (116). This and other ATIC structures that followed, including the structure of human ATIC (117), advanced the understanding of the mechanism of action of ATIC and existing ATIC inhibitors and aided in the design of more potent and specific ATIC inhibitors (36, 118-121). 
Under physiological conditions, Z-nucleotides and nucleosides are present only in low intracellular concentrations $(61,70)$. Indeed, even during treatment with low AICAR concentrations ZMP can remain below detection level (30). However, pharmacological inhibition of ATIC promotes intracellular accumulation of ZMP $(29,30,37$, $58,122)$. Further, deficiency of ATIC in humans results in marked intracellular accumulation of ZMP and high urinary concentrations of AICAR (AICA-ribosiduria) $(61,123)$, which highlights that ATIC is essential for normal ZMP and AICAR turnover. Indeed, deficiency of ATIC in humans leads to severe phenotype, characterized by blindness, mental retardation, epilepsy, and dysmorphia, underlining the physiological importance of ATIC (61). Increased intracellular concentrations of ZTP were also observed in subjects with the Lesch-Nyhan syndrome, which is characterized by deficient salvage pathway of purine synthesis, and 5-phosphoribosyl-1-pyro- phosphate synthetase (Figure 1) overactivity (70), which both increase flux through the de novo pathway. Taken together, these studies show that increases in Z-nucleotide concentrations can be expected when ATIC function is suppressed or activity of the de novo pathway is markedly increased.

\section{De novo purine synthesis and ATIC in skeletal muscle}

ATIC is expressed in cultured skeletal muscle cells and skeletal muscle tissue $(30,104,115,124)$. Further, the de novo purine synthesis pathway is active in cultured skeletal muscle cells (125-128) as well as skeletal muscle (125, 129, 130), indicating ATIC is functionally important for muscle physiology. Treatment with exogenous AICAR in dogs results in marked increase in muscle IMP concentrations (59), which again indicates that ATIC is functional

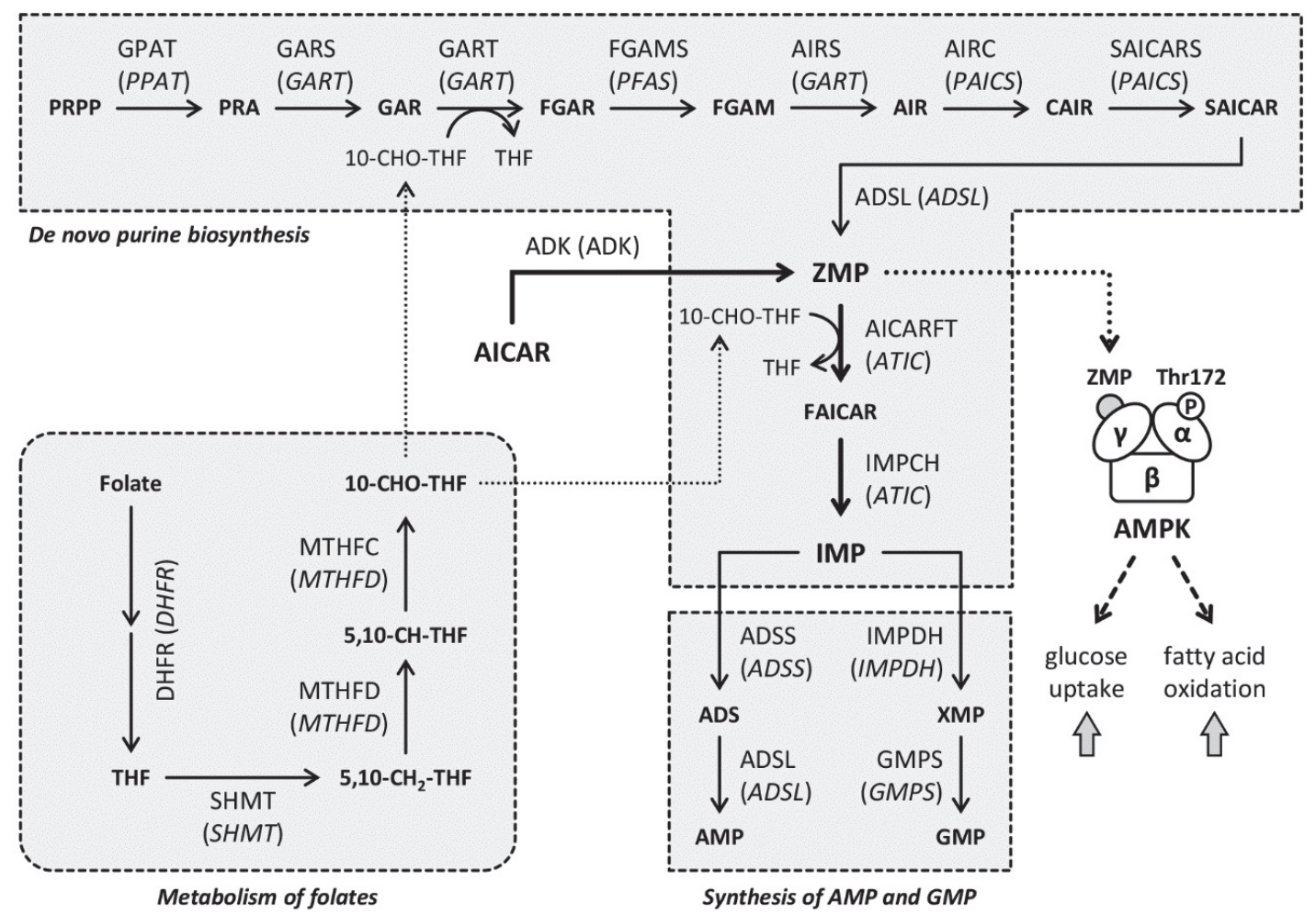

Figure 1. De novo purine biosynthesis and AMPK activation. Full arrows indicate enzymatic reactions. Enzymatic activity and the gene encoding this enzymatic activity (in parentheses) are indicated for each enzymatic reaction. Intermediates: PRPP: 5-phosphoribosyl-1-pyrophosphate, PRA: phosphoribosylamine, GAR: glycinamide ribonucleotide, FGAR: formylglycinamide ribonucleotide, FGAM: formylglycinamidine ribonucleotide, AIR: 5-aminoimidazole ribonucleotide, CAIR: carboxyaminoimidazole ribonucleotide, SAICAR: $N$-succinyl-5-aminoimidazole4-carboxamide ribonucleotide, ZMP: 5-aminoimidazole-4-carboxamide ribonucleotide, FAICAR: 5-formaminoimidazole-4-carboxamide ribonucleotide, IMP: inosine monophosphate, ADS: adenylosuccinate, AMP: adenosine monophosphate, XMP: xanthosine monophosphate, GMP: guanosine monophosphate, THF: tetrahydrofolate, AICAR: 5-amino-4-imidazolecarboxamide riboside. Enzymes: GPAT: glutamine phosphoribosylpyrophosphate amidotransferase, GARS: glycinamide ribonucleotide synthetase, GART: glycinamide ribonucleotide formyltransferase, FGAMS: formylglycinamidine ribonucleotide synthase; AIRS: aminoimidazole ribonucleotide synthetase, AIRC: aminoimidazole ribonucleotide carboxylase, SAICARS: succinylaminoimidazolecarboxamide ribonucleotide synthetase, ADSL: adenylosuccinate lyase, AICARFT: 5-aminoimidazole-4-carboxamide ribonucleotide formyltransferase, IMPCH: IMP cyclohydrolase, ADSS: adenylosuccinate synthetase, IMPDH: IMP dehydrogenase, GMPS: GMP synthetase, ADK: adenosine kinase, DHFR: dihydrofolate reductase, SHMT: serine hydroxymethyltransferase, MTHFD: methylenetetrahydrofolate dehydrogenase; $M$ THFC: methenyltetrahydrofolate cyclohydrolase; $A M P K:$ AMP-activated protein kinase. 
in skeletal muscle. According to measurements in rat skeletal muscle, $0.3-1 \%$ of the total adenine nucleotide pool is turned over per hour (131). However, the extent to which purines are synthesized via the de novo pathway depends also on activity of the salvage pathway, which suppresses de novo synthesis (132). In skeletal muscle, de novo synthesis is thought to be particularly important after contractions, which result in a massive loss of adenine nucleotides from muscle into the bloodstream (133).

\section{ATIC as an entry point to modulate energy metabolism via AMPK in skeletal muscle?}

ATIC is directly or indirectly suppressed by several antirheumatic drugs (Table 2): methotrexate, sulfasalazine, non-steroidal antirheumatic drugs (NSAID), and azathioprine. Interestingly, folinic acid (leucovorin), which is used to reduce methotrexate toxicity, also inhibits ATIC (134). While all these drugs have several other targets, notably dihydrofolate reductase in the case of methotrexate and cyclooxigenases in the case of NSAID, suppression of ATIC is thought to be particularly important for antirheumatic actions of methotrexate and sulfasalazine $(57,122,135,136)$. Methotrexate and sulfasalazine are especially interesting because they are widely used for chronic treatment of rheumatic diseases.

Antirheumatic treatment reduces the risk of diabetes in subjects with rheumatoid arthritis or psoriasis (7). Suppression of inflammation likely represents one mechanism that underlies metabolic improvements with antirheumatic treatment (144). However, direct metabolic effects of antirheumatic drugs could also contribute. Indeed, while all drugs used for treatment of inflammatory rheumatic diseases suppress inflammation and immune function, they are not all equally effective at reducing the risk of diabetes $(7,8)$. The most effective seem to be inhibitors of tumour necrosis factor- $\alpha$ (TNF- $\alpha$ ) and hydroxychloroquine $(7,8,145)$, neither of which acts via ATIC.

Dysregulated TNF- $\alpha$ signalling plays a major role in pathogenesis of rheumatic diseases and its suppression with biologicals, such as etanercept and infliximab, effectively suppresses their progression $(146,147)$. Infusion of TNF- $\alpha$ opposes insulin-stimulated glucose disposal in humans $(148,149)$. It is therefore not surprising that suppression of TNF- $\alpha$ in rheumatic patients protects against diabetes (7, 8). Hydroxychloroquine is an antirheumatic and antimalarial drug that has recently been in focus of intense research efforts since it suppresses severe acute respiratory syndromecoronavirus-2 (SARS-CoV-2) in vitro $(150,151)$ and might be useful for treatment of coronavirus disease-19 (COVID-19), although its clinical effectiveness needs to be verified (152-157). Use of hydroxychloroquine in rheumatic patients has been linked to improvements in metabolic status and protection against diabetes (158). Mechanism of action of hydroxychloroquine involves inhibition of lyso- somal activity, autophagy, and Toll-like receptor signalling, but how these effects lead to improvements in metabolic homeostasis has not been established (159).

Although less potent as regards metabolic actions, methotrexate has also been rather consistently linked with at least mild improvements in glucose homeostasis and/or protection against diabetes (Table 3). Methotrexate (amethopterin) is a folate antagonist that was first used for treatment of cancer (160). Anticancer effects of high doses of methotrexate, which may lead to peak plasma concentrations as high as $1000 \mu \mathrm{M}$ (or more) (161), are thought to be the result of inhibition of dihydrofolate reductase, which suppresses thymidylate and consequently DNA synthesis, although inhibition of ATIC and other enzymes also contributes (34). In rheumatology, low-dose methotrexate is used $(63,96,146,162)$, which produces peak plasma concentrations below $1 \mu \mathrm{M}(-100-500 \mathrm{nM})(163-165)$. During treatment with low-dose methotrexate, inhibition of ATIC is thought to be particularly important for antirheumatic effects of methotrexate $(57,58,166)$.

Sulfasalazine, a conjugate of 5 -aminosalicylic acid and sulfapyridine, is another widely used antirheumatic drug (146). However, compared with methotrexate, relatively few studies examined metabolic effects of sulfasalazine. Molecular mechanisms underlying its anti-inflammatory and immunosuppressive effects are complex $(167,168)$, involving modulation of various cellular processes, including inhibition of ATIC $(32,122)$. Interestingly, sulfasalazine has been suggested to reduce blood glucose concentrations in patients with type 2 diabetes (169). Further, animal studies suggest sulfasalazine may protect against diabetic retinopathy and neuropathy $(167,168)$.

An important question is whether antirheumatic drugs, such as methotrexate and sulfasalazine, can exert protective metabolic effects by inhibiting ATIC and promoting AMPK activation in skeletal muscle. There are at least four lines of evidence directly or indirectly supporting this notion. First, methotrexate was shown to activate AMPK or enhance AICAR-stimulated AMPK activation in cultured cancer and skeletal muscle cells $(29,30,104)$. Further, methotrexate enhances AICAR-stimulated AMPK activation and downstream metabolic effects in isolated mouse skeletal muscle (30). Second, in vivo evidence supports the notion that methotrexate can activate AMPK in tissues. Indeed, methotrexate increased phosphorylation of AMPK not only in cultured human umbilical vascular endothelial cells, but also in aorta in mice in vivo (194). Third, in the $d b / d b$ mice methotrexate upregulated GLUT4 in skeletal muscle and reduced serum glucose and insulin concentrations (174), which is consistent with muscle AMPK activation. Finally, Cpd14, a new experimental ATIC inhibitor, activates AMPK and improves glucose homeostasis in obese mice (36).

As mentioned above, ATIC is not the only pharmacological target of methotrexate. Other targets are dihydro- 
Table 2. Overview of antirheumatic drugs that inhibit ATIC. $K_{i}$ values may depend on the enzyme used in the assay (human or chicken) and on the assay conditions. Source of the enzyme is indicated in the table while assay conditions can be found in the references. References are listed chronologically. Abbreviations: DMARD - disease modifying antirheumatic drugs; NSAID - non-steroidal anti-inflammatory (antirheumatic) drugs; PBMC-peripheral blood mononuclear cell; 7-OH-MTX - 7-hydroxy-MTX (a major metabolite of MTX).

\begin{tabular}{|c|c|c|c|}
\hline Class & Drug & Inhibition of ATIC activity & Refs. \\
\hline \multirow[t]{16}{*}{ DMARD } & \multirow[t]{13}{*}{ Methotrexate (MTX), amethopterin } & $\begin{array}{l}\text { MTX increases urinary AICA excretion in patients with } \\
\text { leukemia. }\end{array}$ & $(137,138)$ \\
\hline & & $\begin{array}{l}\text { MTX-pentaglutamate is }>2,000 \text {-fold more effective inhibitor of } \\
\text { ATIC than MTX-monoglutamate. }\end{array}$ & $(34,35)$ \\
\hline & & $\begin{array}{l}\text { MTX is a non-competitive inhibitor, while polyglutamylated MTX } \\
\text { acts as a competitive inhibitor; polyglutamylated MTX inhibits } \\
\text { chicken liver ATIC with } K_{\mathrm{i}} \text { of } 3.15 \mu \mathrm{M} \text {. }\end{array}$ & (33) \\
\hline & & MTX produces ZMP accumulation in cultured MCF-7 cells. & (139) \\
\hline & & $\begin{array}{l}\text { MTX (in low concentrations) produces ZMP accumulation in } \\
\text { malignant lymphoblasts. }\end{array}$ & $(140)$ \\
\hline & & $\begin{array}{l}\text { 7-OH-MTX inhibits human ATIC (from MCF-7 breast cancer } \\
\text { cells) with } K_{\mathrm{i}} \text { of } 0.03-180 \mu \mathrm{M}\left(K_{i} \text { depends on the folate cofactor }\right. \\
\text { and glutamylation of } 7-\mathrm{OH}-\mathrm{MTX}) \text {. }\end{array}$ & (141) \\
\hline & & MTX inhibits chicken liver ATIC with $K_{\mathrm{i}}$ of $0.11 \mathrm{mM}$. & (32) \\
\hline & & $\begin{array}{l}\text { Treatment with MTX increases ZMP concentration in murine } \\
\text { splenocytes (in vivo). }\end{array}$ & (58) \\
\hline & & 7-OH-MTX inhibits chicken liver ATIC with $K_{\mathrm{i}}$ of $133 \mu \mathrm{M}$. & $(142)$ \\
\hline & & MTX increases urinary AICA excretion in patients with psoriasis. & (69) \\
\hline & & $\begin{array}{l}\text { MTX increases urinary AICA excretion in patients with rheumatoid } \\
\text { arthritis. }\end{array}$ & (63) \\
\hline & & $\begin{array}{l}\text { MTX enhances ZMP accumulation in AICAR-treated } \\
\text { MDA-MB-231 cells. }\end{array}$ & (29) \\
\hline & & $\begin{array}{l}\text { MTX enhances ZMP accumulation in AICAR-treated skeletal } \\
\text { muscle cells in vitro. }\end{array}$ & (30) \\
\hline & \multirow{2}{*}{$\begin{array}{l}\text { Sulfasalazine (SSZ), sulphasalazine, } \\
\text { alazosulfapyridine, salicylazosulfapyridine, } \\
\text { salazopyrin, azulfidine, sulfazine, azopyrin }\end{array}$} & Sulfasalazine inhibits chicken liver ATIC with $K_{\mathrm{i}}$ of $22 \mu \mathrm{M}$. & (32) \\
\hline & & $\begin{array}{l}\text { Sulfasalazine increases } \mathrm{ZMP} \text { content in murine splenocytes } \\
\text { (in vivo). }\end{array}$ & $(122)$ \\
\hline & $\begin{array}{l}\text { Azathioprine, } \\
\text { imuran }\end{array}$ & $\begin{array}{l}\text { Azathioprine and its metabolite thioinosinic acid (TIMP) } \\
\text { are competitive inhibitors of ATIC from chicken liver }\left(K_{\mathrm{i}} \text { for }\right. \\
\text { azathioprine and TIMP are } 120 \text { and } 39 \mu \mathrm{M} \text {, respectively) and } \\
\text { mouse PBMCs }\left(K_{\mathrm{i}} \text { for azathioprine and TIMP are } 90 \text { and }\right. \\
110 \mu \mathrm{M} \text {, respectively). }\end{array}$ & (143) \\
\hline \multirow[t]{9}{*}{ NSAID } & Aspirin & $K_{\mathrm{i}}=11 \mathrm{mM}$ (chicken liver ATIC) & (32) \\
\hline & \multirow[t]{2}{*}{ Ibuprofen } & $\begin{array}{l}\text { Chicken liver ATIC is inhibited by } 14-22 \% \text { with } 2 \mathrm{mM} \\
\text { ibuprofen. }\end{array}$ & (143) \\
\hline & & $K_{\mathrm{i}}=1.5 \mathrm{mM}$ (chicken liver ATIC) & $(32)$ \\
\hline & Indomethacin & $K_{\mathrm{i}}=0.35 \mathrm{mM}$ (chicken liver ATIC) & $(32)$ \\
\hline & Mefenamic acid & $K_{\mathrm{i}}=3.8 \mathrm{mM}$ (chicken liver ATIC) & $(32)$ \\
\hline & \multirow[t]{2}{*}{ Naproxen } & Chicken liver ATIC inhibited by $32-46 \%$ with $2 \mathrm{mM}$ naproxen. & (143) \\
\hline & & $K_{\mathrm{i}}=0.99 \mathrm{mM}$, (chicken liver ATIC) & (32) \\
\hline & Salicylic acid & $K_{\mathrm{i}}=1.1 \mathrm{mM}$ (chicken liver ATIC) & $(32)$ \\
\hline & Sulindac & $K_{\mathrm{i}}=0.13 \mathrm{mM}$ (chicken liver ATIC) & $(32)$ \\
\hline Folate & $\begin{array}{l}\text { Leucovorin, } \\
\text { folinic acid, } \\
5 \text {-formyltetrahydrofolic acid }\end{array}$ & $\begin{array}{l}\text { Leucovorin pentaglutamate inhibits human ATIC (from MCF7 } \\
\text { cells) with } K_{\mathrm{i}} \text { of } 3 \mu \mathrm{M} \text {. }\end{array}$ & $(134)$ \\
\hline
\end{tabular}


Table 3. Metabolic effects of antirheumatic drugs that inhibit ATIC. References are listed chronologically. Abbreviations: RA - rheumatoid arthritis; PsA - psoriatic arthritis; T2D - type 2 diabetes.

\begin{tabular}{|c|c|c|}
\hline Drug & Metabolic effects & Refs. \\
\hline \multirow[t]{12}{*}{$\begin{array}{l}\text { Methotrexate } \\
\text { (MTX) }\end{array}$} & $\begin{array}{l}\text { MTX decreased glycogen content of the liver and glucose level and level of nonesterified fatty acids in the liver } \\
\text { perfusate (experiment with isolated perfused rat liver). }\end{array}$ & $(170)$ \\
\hline & MTX activated glucose release from endogenous glycogen (glycogenolysis) (experiment with isolated perfused rat liver). & $(171)$ \\
\hline & MTX reduced risk of metabolic syndrome in RA patients older than 60 years. & (172) \\
\hline & $\begin{array}{l}\text { MTX did not significantly reduce } \mathrm{HbA}_{1 \mathrm{c}} \text { concentration in diabetes patients with RA. } \\
\text { (However, the study was not powered to detect a difference in MTX.) }\end{array}$ & $(145)$ \\
\hline & MTX treatment of RA or PsA was linked to reduced risk of developing diabetes. & (7) \\
\hline & $\begin{array}{l}\text { Obese mice treated with MTX displayed reduced serum levels of insulin and glucose, and an improvement of } \\
\text { insulin sensitivity. }\end{array}$ & (173) \\
\hline & $\begin{array}{l}\text { MTX increased skeletal muscle GLUT4 mRNA expression and GLUT4 protein level and reduced serum glucose } \\
\text { and insulin levels in diabetic }(d b / d b) \text { mice. }\end{array}$ & (174) \\
\hline & Long-term MTX therapy was associated with a lower rate of dyslipidemia. & $(175)$ \\
\hline & MTX therapy and MTX-polyglutamates were associated with lower concentrations of $\mathrm{HbA}_{1 \mathrm{c}}$ in patients with RA. & (11) \\
\hline & $\begin{array}{l}\text { MTX reduced concentration of } \mathrm{HbA}_{1 c} \text { in patients with RA or PsA, but urinary AICAR or erythrocyte ZMP were } \\
\text { not increased. }\end{array}$ & (96) \\
\hline & MTX numerically (but non-significantly) reduced the risk of diabetes in RA patients. & (8) \\
\hline & $\begin{array}{l}\text { MTX in PsA patients did not appear to have hyperglycaemic effects (there were no significant changes between } \\
\mathrm{HbA}_{1 \mathrm{c}} \text { levels before and after MTX therapy). }\end{array}$ & $(176)$ \\
\hline \multirow{3}{*}{$\begin{array}{l}\text { Sulfasalazine } \\
\text { (SSZ) }\end{array}$} & SZZ was linked to increased risk of hypoglycaemia and improved glycaemic control in T2D. & $(169)$ \\
\hline & $\begin{array}{l}\text { SSZ prevented loss of retinal ganglion cells and degeneration of retinal capillaries in diabetic (streptozocin-treated) } \\
\text { rats, indicating it protects against diabetic retinopathy. }\end{array}$ & $(167)$ \\
\hline & $\begin{array}{l}\text { SSZ blocked development of tactile allodynia and ameliorated mechanical hyperalgesia in diabetic (streptozocin- } \\
\text { treated) rats, indicating it protects against diabetic neuropathy. }\end{array}$ & $(168)$ \\
\hline Leucovorin & Leucovorin reduced glucose uptake and storage of glycogen in isolated rat diaphragm. & $(177)$ \\
\hline Naproxen & $\begin{array}{l}\text { Naproxen reduced serum glucose levels and increased hepatic glycogen and serum insulin levels in normal and dia- } \\
\text { betic (streptozocin-treated) mice. Naproxen also reduced weight, serum glucose and resistin levels, while it elevated } \\
\text { serum insulin, C-peptide, and adiponectin levels in obese mice. }\end{array}$ & (178) \\
\hline \multirow[t]{14}{*}{ Salicylate } & Salicylate reduced glycosuria in a patient with diabetes mellitus. & $(179)$ \\
\hline & Salicylate reduced glycosuria and blood glucose concentrations in diabetic (alloxan-treated) rats. & $(180)$ \\
\hline & Salicylate reduced glycosuria and hyperglycaemia in rats treated with cortisone. & $(181)$ \\
\hline & Salicylate reduced liver glycogen content in mice. & $(182)$ \\
\hline & Salicylate caused hyperglycaemia in rats. & (183) \\
\hline & Salicylate increased glucose uptake in perfused rat hearts. & (184) \\
\hline & $\begin{array}{l}\text { Salicylate increased plasma insulin levels and reduced plasma glucose levels in mild diabetic patients. Salicylate also } \\
\text { improved glucose tolerance in these patients. }\end{array}$ & $(185)$ \\
\hline & Salicylate inhibited the development of diabetic retinopathy. & $(167)$ \\
\hline & $\begin{array}{l}\text { Salicylate prevented fat-induced insulin resistance in rats: salicylate prevented lipid-induced decrease in whole body } \\
\text { and skeletal muscle glucose uptake, skeletal muscle glycolysis and glycogen synthesis. }\end{array}$ & (186) \\
\hline & Salicylate was shown to be a direct AMPK activator. & (31) \\
\hline & $\begin{array}{l}\text { Salsalate (a prodrug of salicylate) reduced } \mathrm{HbA}_{1 \mathrm{c}} \text { in diabetic patients. Fasting glucose and triglyceride levels de- } \\
\text { creased with salsalate, but weight and low-density lipoprotein cholesterol levels increased. }\end{array}$ & (187) \\
\hline & $\begin{array}{l}\text { Salicylate activated AMPK, stimulated glucose uptake and decreased ATP, phosphocreatine, and glycogen contents } \\
\text { in rat skeletal muscles. }\end{array}$ & (188) \\
\hline & Salicylate uncoupled mitochondria and improved glucose homeostasis in mice independently of AMPK. & (81) \\
\hline & Salicylate attenuated development of diabetic nephropathy in diabetic mice. & (189) \\
\hline
\end{tabular}




\begin{tabular}{|l}
\hline Aspirin \\
Aspirin abolished glycosuria and lowered the fasting blood sugar to normal or near normal in mild to moderately \\
severe diabetic patients. \\
Aspirin decreased serum glucose response and increased serum insulin response to oral glucose in normal and \\
diabetic subjects. Aspirin also decreased fasting serum free fatty acids in normal and diabetic subjects and fasting \\
serum triglycerides in diabetic patients. \\
Aspirin prevented the increase in plasma glucose levels and attenuated the rise in insulin levels as well as insulin \\
resistance in the glucose-fed rats. \\
Aspirin inhibited the development of diabetic retinopathy. \\
Aspirin attenuated insulin resistance in muscles of obese rats: aspirin reversed diet-induced decrease of insulin- \\
induced Tyr phosphorylation of insulin receptor $\beta$ and IRS-1 and Ser phosphorylation of Akt. \\
(1963)
\end{tabular}

folate reductase, methylenetetrahydrofolate reductase, thymidylate synthase, as well as glycinamide ribonucleotide formyltransferase (GART) $(34,57)$. Notably, GART is an enzyme upstream of ATIC in the de novo pathway of purine synthesis (Figure 1), whose inhibition would therefore tend to suppress de novo synthesis, reduce endogenous intracellular ZMP levels (140), and AMPK activity. In its native (monoglutamate) form methotrexate is approximately equally effective inhibitor of GART and ATIC (34). However, once inside the cell methotrexate is glutamylated and methotrexate-polyglutamates are much more effective ATIC inhibitors than GART inhibitors (34). Due to formation of methotrexate-polyglutamates, exposure to low concentrations of methotrexate primarily inhibits ATIC, thus leading to intracellular accumulation of endogenous ZMP (140). Consistent with this notion, low-dose methotrexate, which is used for treatment of rheumatic diseases, produces intracellular accumulation of ZMP in mice (58) and increases urinary excretion of ZMP metabolite AICA in subjects with rheumatoid or psoriatic arthritis $(63,69)$. In contrast, exposure to high concentrations of methotrexate inhibits both enzymes, which blocks ZMP synthesis and accumulation despite ATIC inhibition (140). Under these conditions, methotrexate alone does not activate AMPK, but it effectively enhances AMPK activation by exogenous $\operatorname{AICAR}(29,30,104)$.

Finally, it needs to be emphasized that methotrexate, even when used in low dosages, might lead to toxicity, including suppression of the bone marrow, loss of hair, and liver fibrosis $(57,195,196)$. In addition, therapy with methotrexate may lead to a small increase in the risk of skin cancer (196). Although adverse effects can be controlled to some extent by administration of folic or folinic acid (leucovorin) (196-198), toxicity of methotrexate or related compounds would be a limiting factor in treatment of metabolic disorders. Nevertheless, patients who need methotrexate to treat their rheumatic disease might benefit from its metabolic effects.

\section{CONCLUSIONS AND PERSPECTIVES}

In summary, antirheumatic drugs that inhibit ATIC, such as methotrexate, might exert direct metabolic effects by promoting AMPK activation in skeletal muscle and other tissues. Activation of AMPK would tend to benefit patients with inflammatory rheumatic diseases by ameliorating metabolic dysregulation. Further, AMPK activation was linked to suppression of inflammation $(199,200)$, indicating AMPK might be important for anti-inflammatory and immunosuppressive effects of these drugs. Several effective anti-inflammatory and immunosuppressive drugs promote metabolic dysregulation, especially when used in combination $(8,10,11)$. In contrast, antirheumatic drugs that also inhibit ATIC seem to be beneficial for controlling both inflammation and metabolic dysregulation. Development of new compounds with such characteristics might therefore be particularly relevant for patients with chronic inflammatory diseases and increased risk of metabolic dysregulation, including type 2 diabetes. Finally, since chronic low-grade inflammation plays a role in obesity and type 2 diabetes $(18,201)$, compounds that simultaneously oppose both pathological processes might also be useful for treatment of metabolic diseases.

Acknowledgements: S.P. and K.D. are supported by funding from the Slovenian Research Agency [grants P30043, J7-8276, and grant for bilateral cooperation between Republic of Slovenia and Republic of Croatia BIHR/20-21-041]. A.V.C. is supported by funding from the Russian Science Foundation [grant No. 19-15-00118] and the Strategic Research Programme in Diabetes at Karolinska Institutet. S.P. and A.V.C are also supported by the bilateral grant for research cooperation between Republic of Slovenia and Russian Federation funded by the Slovenian Research Agency [grant BI-RU/19-20-039].

\section{REFERENCES}

1. OECD/EU 2018 Health at a Glance: Europe 2018: State of Health in the EU Cycle. OECD Publishing. https://www.oecd-ilibrary. org/content/publication/health_glance_eur-2018-en

2. CHUNG CP, OESER A, SOLUS JF, GEBRETSADIK T, SHINTANI A, AVALOS I, SOKKA T, RAGGI P, PINCUS T, STEIN CM 2008 Inflammation-associated insulin resistance: differential effects in rheumatoid arthritis and systemic lupus erythematosus define potential mechanisms. Arthritis Rheum 58: 2105-2112. https://doi.org/10.1002/art.23600 
3. SOLOMON DH, LOVE TJ, CANNING C, SCHNEEWEISS S 2010 Risk of diabetes among patients with rheumatoid arthritis, psoriatic arthritis and psoriasis. Ann Rheum Dis 69: 2114-2117. https://doi.org/10.1136/ard.2009.125476

4. CHUNG CP, OESER A, SOLUS JF, AVALOS I, GEBRETSADIK T, SHINTANI A, RAGGI P, SOKKA T, PINCUS T, STEIN CM 2008 Prevalence of the metabolic syndrome is increased in rheumatoid arthritis and is associated with coronary atherosclerosis. Atherosclerosis 196: 756-763.

https://doi.org/10.1016/j.atherosclerosis.2007.01.004

5. CHUNG CP, AVALOS I, OESER A, GEBRETSADIK T, SHINTANI A, RAGGI P, STEIN C M 2007 High prevalence of the metabolic syndrome in patients with systemic lupus erythematosus: association with disease characteristics and cardiovascular risk factors. Ann Rheum Dis 66: 208-214.

https://doi.org/10.1136/ard.2006.054973

6. FERGUSON LD, SIEBERT S, MCINNES IB, SATTAR N 2019 Cardiometabolic comorbidities in RA and PsA: lessons learned and future directions. Nat Rev Rheumatol 15: 461-474.

https://doi.org/10.1038/s41584-019-0256-0

7. SOLOMON DH, MASSAROTTI E, GARG R, LIU J, CANNING C, SCHNEEWEISS S 2011 Association between diseasemodifying antirheumatic drugs and diabetes risk in patients with rheumatoid arthritis and psoriasis. JAMA 305: 2525-2531. https://doi.org/10.1001/jama.2011.878

8. LILLEGRAVEN S, GREENBERG JD, REED GW, SAUNDERS K, CURTIS JR, HARROLD L, HOCHBERG MC, PAPPAS DA, KREMER JM, SOLOMON DH 2019 Immunosuppressive treatment and the risk of diabetes in rheumatoid arthritis. PLoS One 14: e0210459. https://doi.org/10.1371/journal.pone.0210459

9. RIDKER PM, EVERETT BM, PRADHAN A, MACFADYEN JG, SOLOMON DH, ZAHARRIS E, MAM V, HASAN A, ROSENBERG Y, ITURRIAGA E, GUPTA M, TSIGOULIS M, VERMA S, CLEARFIELD M, LIBBY P, GOLDHABER SZ, SEAGLE R, OFORI C, SAKLAYEN M, BUTMAN S, SINGH N, LE MAY M, BERTRAND O, JOHNSTON J, PAYNTER NP, GLYNN RJ, INVESTIGATORS C 2019 Low-dose methotrexate for the prevention of atherosclerotic events. N Engl J Med 380: 752-762. https://doi.org/10.1056/NEJMoa1809798

10. JENSSEN T, HARTMANN A 2019 Post-transplant diabetes mellitus in patients with solid organ transplants. Nat Rev Endocrinol 15: 172-188. https://doi.org/10.1038/s41574-018-0137-7

11. DE ROTTE MC, DE JONG PH, DEN BOER E, PLUIJM SM, OZCAN B, WEEL AE, LINDEMANS J, HAZES JM, DE JONGE R 2014 Effect of methotrexate use and erythrocyte methotrexate polyglutamate on glycosylated hemoglobin in rheumatoid arthritis. Arthritis Rheumatol 66: 2026-2036.

https://doi.org/10.1002/art.38652

12. ZURLO F, LARSON K, BOGARDUS C, RAVUSSIN E 1990 Skeletal muscle metabolism is a major determinant of resting energy expenditure. J Clin Invest 86: 1423-1427. https://doi.org/10.1172/JCI114857

13. DEFRONZO RA, GUNNARSSON R, BJORKMAN O, OLSSON M, WAHREN J 1985 Effects of insulin on peripheral and splanchnic glucose metabolism in noninsulin-dependent (type II) diabetes mellitus. J Clin Invest 76: 149-155.

https://doi.org/10.1172/JCI111938

14. CLINE GW, PETERSEN KF, KRSSAK M, SHEN J, HUNDAL RS, TRAJANOSKI Z, INZUCCHI S, DRESNER A, ROTHMAN DL, SHULMAN GI 1999 Impaired glucose transport as a cause of decreased insulin-stimulated muscle glycogen synthesis in type 2 diabetes. N Engl J Med 341: 240-246. https://doi.org/10.1056/NEJM199907223410404

15. DEFRONZO RA 1988 Lilly lecture 1987. The triumvirate: betacell, muscle, liver. A collusion responsible for NIDDM. Diabetes 37: 667-687. https://doi.org/10.2337/diab.37.6.667
16. LONG YC, ZIERATH JR 2006 AMP-activated protein kinase signaling in metabolic regulation. J Clin Invest 116: 1776-1783. https://doi.org/10.1172/JCI29044

17. HARDIE DG 2013 AMPK: a target for drugs and natural products with effects on both diabetes and cancer. Diabetes 62: 21642172. https://doi.org/10.2337/db13-0368

18. STEINBERG GR, CARLING D 2019 AMP-activated protein kinase: the current landscape for drug development. Nat Rev Drug Discov 18: 527-551. https://doi.org/10.1038/s41573-019-0019-2

19. MERRILL GF, KURTH EJ, HARDIE DG, WINDER WW 1997 AICA riboside increases AMP-activated protein kinase, fatty acid oxidation, and glucose uptake in rat muscle. Am J Physiol 273: E1107-1112. https://doi.org/10.1152/ajpendo.1997.273.6.E1107

20. FISHER JS, GAO J, HAN DH, HOLLOSZY JO, NOLTE LA 2002 Activation of AMP kinase enhances sensitivity of muscle glucose transport to insulin. Am J Physiol Endocrinol Metab 282: E18-23. https://doi.org/10.1152/ajpendo.2002.282.1.E18

21. IGLESIAS MA, YE JM, FRANGIOUDAKIS G, SAHA AK, TOMAS E, RUDERMAN NB, COONEY GJ, KRAEGEN EW 2002 AICAR administration causes an apparent enhancement of muscle and liver insulin action in insulin-resistant high-fat-fed rats. Diabetes 51: 2886-2894.

https://doi.org/10.2337/diabetes.51.10.2886

22. BUHL ES, JESSEN N, SCHMITZ O, PEDERSEN SB, PEDERSEN O, HOLMAN GD, LUND S 2001 Chronic treatment with 5-aminoimidazole-4-carboxamide-1-beta-D-ribofuranoside increases insulin-stimulated glucose uptake and GLUT4 translocation in rat skeletal muscles in a fiber type-specific manner. Diabetes 50: 12-17. https://doi.org/10.2337/diabetes.50.1.12

23. POLD R, JENSEN LS, JESSEN N, BUHL ES, SCHMITZ O, FLYVBJERG A, FUJII N, GOODYEAR LJ, GOTFREDSEN CF, BRAND CL, LUND S 2005 Long-term AICAR administration and exercise prevents diabetes in ZDF rats. Diabetes 54: 928-934. https://doi.org/10.2337/diabetes.54.4.928

24. BUHL ES, JESSEN N, POLD R, LEDET T, FLYVBJERG A, PEDERSEN SB, PEDERSEN O, SCHMITZ O, LUND S 2002 Long-term AICAR administration reduces metabolic disturbances and lowers blood pressure in rats displaying features of the insulin resistance syndrome. Diabetes 51: 2199-2206. https://doi.org/10.2337/diabetes.51.7.2199

25. SCOTT JW, VAN DENDEREN BJ, JORGENSEN SB, HONEYMAN JE, STEINBERG GR, OAKHILL JS, ISELI TJ, KOAY A, GOOLEY PR, STAPLETON D, KEMP BE 2008 Thienopyridone drugs are selective activators of AMP-activated protein kinase beta1-containing complexes. Chem Biol 15: 1220-1230. https://doi.org/10.1016/j.chembiol.2008.10.005

26. WOJTASZEWSKI JF, BIRK JB, FROSIG C, HOLTEN M, PILEGAARD H, DELA F 2005 5'AMP activated protein kinase expression in human skeletal muscle: effects of strength training and type 2 diabetes. J Physiol 564: 563-573. https://doi.org/10.1113/jphysiol.2005.082669

27. TREEBAK JT, BIRK JB, HANSEN BF, OLSEN GS, WOJTASZEWSKI JF 2009 A-769662 activates AMPK beta1containing complexes but induces glucose uptake through a PI3kinase-dependent pathway in mouse skeletal muscle. Am J Physiol Cell Physiol 297: C1041-1052.

https://doi.org/10.1152/ajpcell.00051.2009

28. DIXON R, GOURZIS J, MCDERMOTT D, FUJITAKI J, DEWLAND P, GRUBER H 1991 AICA-riboside: safety, tolerance, and pharmacokinetics of a novel adenosine-regulating agent. J Clin Pharmacol 31: 342-347.

https://doi.org/10.1002/j.1552-4604.1991.tb03715.x

29. BECKERS A, ORGANE S, TIMMERMANS L, VANDERHOYDONC F, DEBOEL L, DERUA R, WAELKENS E, BRUSSELMANS K, VERHOEVEN G, SWINNEN JV 2006 Methotrexate enhances the antianabolic and antiproliferative effects of 
5-aminoimidazole-4-carboxamide riboside. Mol Cancer Ther 5: 2211-2217. https://doi.org/10.1158/1535-7163.MCT-06-0001

30. PIRKMAJER S, KULKARNI S S, TOM RZ, ROSS FA, HAWLEY SA, HARDIE DG, ZIERATH JR, CHIBALIN AV 2015 Methotrexate promotes glucose uptake and lipid oxidation in skeletal muscle via AMPK activation. Diabetes 64: 360-369. https://doi.org/10.2337/db14-0508

31. HAWLEY SA, FULLERTON MD, ROSS FA, SCHERTZER JD, CHEVTZOFF C, WALKER KJ, PEGGIE MW, ZIBROVA D, GREEN KA, MUSTARD KJ, KEMP BE, SAKAMOTO K, STEINBERG GR, HARDIE DG 2012 The ancient drug salicylate directly activates AMP-activated protein kinase. Science 336: 918-922. https://doi.org/10.1126/science.1215327

32. BAGGOTT JE, MORGAN SL, HA T, VAUGHN WH, HINE RJ 1992 Inhibition of folate-dependent enzymes by non-steroidal anti-inflammatory drugs. Biochem J 282 (Pt 1): 197-202. https://doi.org/10.1042/bj2820197

33. BAGGOTT JE, VAUGHN WH, HUDSON BB 1986 Inhibition of 5-aminoimidazole-4-carboxamide ribotide transformylase, adenosine deaminase and 5'-adenylate deaminase by polyglutamates of methotrexate and oxidized folates and by 5 -aminoimidazole4-carboxamide riboside and ribotide. Biochem J 236: 193-200. https://doi.org/10.1042/bj2360193

34. CHABNER BA, ALLEGRA CJ, CURT GA, CLENDENINN NJ, BARAM J, KOIZUMI S, DRAKE JC, JOLIVET J 1985 Polyglutamation of methotrexate. Is methotrexate a prodrug? J Clin Invest 76: 907-912. https://doi.org/10.1172/JCI112088

35. ALLEGRA CJ, DRAKE J C, JOLIVET J, CHABNER BA 1985 Inhibition of phosphoribosylaminoimidazolecarboxamide transformylase by methotrexate and dihydrofolic acid polyglutamates. Proc Nat Acad Sci USA 82: 4881-4885.

https://doi.org/10.1073/pnas.82.15.4881

36. ASBY DJ, CUDA F, BEYAERT M, HOUGHTON FD, CAGAMPANG FR, TAVASSOLI A 2015 AMPK activation via modulation of de novo purine biosynthesis with an inhibitor of ATIC homodimerization. Chem Biol 22: 838-848.

https://doi.org/10.1016/j.chembiol.2015.06.008

37. RACANELLI AC, ROTHBART SB, HEYER CL, MORAN RG 2009 Therapeutics by cytotoxic metabolite accumulation: pemetrexed causes ZMP accumulation, AMPK activation, and mammalian target of rapamycin inhibition. Cancer Res 69: 5467-5474. https://doi.org/10.1158/0008-5472.CAN-08-4979

38. HARDIE DG, ROSS FA, HAWLEY SA 2012 AMP-activated protein kinase: a target for drugs both ancient and modern. Chem Biol 19: 1222-1236.

https://doi.org/10.1016/j.chembiol.2012.08.019

39. CARLING D, ZAMMIT VA, HARDIE DG 1987 A common bicyclic protein kinase cascade inactivates the regulatory enzymes of fatty acid and cholesterol biosynthesis. FEBS Lett 223: 217-222. https://doi.org/10.1016/0014-5793(87)80292-2

40. CARLING D, CLARKE PR, ZAMMIT VA, HARDIE DG 1989 Purification and characterization of the AMP-activated protein kinase. Copurification of acetyl-CoA carboxylase kinase and 3-hydroxy-3-methylglutaryl-CoA reductase kinase activities. Eur J Biochem 186: 129-136. https://doi.org/10.1111/j.1432-1033.1989.tb15186.x

41. HARDIE DG 2018 Keeping the home fires burning: AMP-activated protein kinase. J R Soc Interface 15:

https://doi.org/10.1098/rsif.2017.0774

42. HARDIE DG, ROSS FA, HAWLEY SA 2012 AMPK: a nutrient and energy sensor that maintains energy homeostasis. Nat Rev Mol Cell Biol 13: 251-262. https://doi.org/10.1038/nrm3311

43. GOWANS GJ, HAWLEY SA, ROSS FA, HARDIE DG 2013 AMP is a true physiological regulator of AMP-activated protein kinase by both allosteric activation and enhancing net phosphory- lation. Cell Metab 18: 556-566.

https://doi.org/10.1016/j.cmet.2013.08.019

44. XIAO B, SANDERS MJ, UNDERWOOD E, HEATH R, MAYER FV, CARMENA D, JING C, WALKER PA, ECCLESTON JF, HAIRE LF, SAIU P, HOWELL SA, AASLAND R, MARTIN SR, CARLING D, GAMBLIN SJ 2011 Structure of mammalian AMPK and its regulation by ADP. Nature 472: 230-233. https://doi.org/10.1038/nature09932

45. DAVIES SP, HELPS NR, COHEN PT, HARDIE DG 1995 5'AMP inhibits dephosphorylation, as well as promoting phosphorylation, of the AMP-activated protein kinase. Studies using bacterially expressed human protein phosphatase- $2 \mathrm{C}$ alpha and native bovine protein phosphatase-2AC. FEBS Lett 377: 421-425. https://doi.org/10.1016/0014-5793(95)01368-7

46. WEEKES J, HAWLEY SA, CORTON J, SHUGAR D, HARDIE DG 1994 Activation of rat liver AMP-activated protein kinase by kinase kinase in a purified, reconstituted system. Effects of AMP and AMP analogues. Eur J Biochem 219: 751-757. https://doi.org/10.1111/j.1432-1033.1994.tb18554.x

47. HAWLEY SA, ROSS FA, CHEVTZOFF C, GREEN KA, EVANS A, FOGARTY S, TOWLER MC, BROWN LJ, OGUNBAYO OA, EVANS AM, HARDIE DG 2010 Use of cells expressing gamma subunit variants to identify diverse mechanisms of AMPK activation. Cell Metab 11: 554-565. https://doi.org/10.1016/j.cmet.2010.04.001

48. HAWLEY SA, PAN DA, MUSTARD KJ, ROSS L, BAIN J, EDELMAN AM, FRENGUELLI BG, HARDIE DG 2005 Calmodulin-dependent protein kinase kinase-beta is an alternative upstream kinase for AMP-activated protein kinase. Cell Metab 2: 9-19. https://doi.org/10.1016/j.cmet.2005.05.009

49. HURLEY RL, ANDERSON KA, FRANZONE JM, KEMP BE, MEANS AR, WITTERS LA 2005 The Ca2+/calmodulin-dependent protein kinase kinases are AMP-activated protein kinase kinases. J Biol Chem 280: 29060-29066. https://doi.org/10.1074/jbc.M503824200

50. WOODS A, DICKERSON K, HEATH R, HONG SP, MOMCILOVIC M, JOHNSTONE SR, CARLSON M, CARLING D $2005 \mathrm{Ca}^{2+} / \mathrm{calmodulin}$-dependent protein kinase kinase-beta acts upstream of AMP-activated protein kinase in mammalian cells. Cell Metab 2: 21-33. https://doi.org/10.1016/j.cmet.2005.06.005

51. LIN SC, HARDIE DG 2017 AMPK: Sensing Glucose as well as cellular energy status. Cell Metab https://doi.org/10.1016/j.cmet.2017.10.009

52. ZHANG CS, HAWLEY SA, ZONG Y, LI M, WANG Z, GRAY A, MA T, CUI J, FENG JW, ZHU M, WU YQ, LI TY, YE Z, LIN SY, YIN H, PIAO HL, HARDIE DG, LIN SC 2017 Fructose-1,6-bisphosphate and aldolase mediate glucose sensing by AMPK. Nature 548: 112-116. https://doi.org/10.1038/nature23275

53. CORTON JM, GILLESPIE JG, HAWLEY SA, HARDIE DG 1995 5-aminoimidazole-4-carboxamide ribonucleoside. A specific method for activating AMP-activated protein kinase in intact cells? Eur J Biochem 229: 558-565. https://doi.org/10.1111/j.1432-1033.1995.tb20498.x

54. DAY P, SHARFF A, PARRA L, CLEASBY A, WILLIAMS M, HORER S, NAR H, REDEMANN N, TICKLE I, YON J 2007 Structure of a CBS-domain pair from the regulatory gammal subunit of human AMPK in complex with AMP and ZMP. Acta Crystallogr D Biol Crystallogr 63: 587-596. https://doi.org/10.1107/S0907444907009110

55. GOMEZ-GALENO JE, DANG Q, NGUYEN TH, BOYER SH, GROTE MP, SUN Z, CHEN M, CRAIGO WA, VAN POELJE PD, MACKENNA DA, CABLE EE, ROLZIN PA, FINN PD, CHI B, LINEMEYER DL, HECKER SJ, ERION MD 2010 A Potent and selective ampk activator that inhibits de novo lipogen- 
esis. ACS Med Chem Lett 1: 478-482.

https://doi.org/10.1021/ml100143q

56. LANGENDORF CG, NGOEI KRW, SCOTT JW, LING NXY, ISSA SMA, GORMAN MA, PARKER MW, SAKAMOTO K, OAKHILL JS, KEMP BE 2016 Structural basis of allosteric and synergistic activation of AMPK by furan-2-phosphonic derivative C2 binding. Nat Commun 7: 10912.

https://doi.org/10.1038/ncomms10912

57. CRONSTEIN BN, AUNE TM 2020 Methotrexate and its mechanisms of action in inflammatory arthritis. Nat Rev Rheumatol 16: 145-154. https://doi.org/10.1038/s41584-020-0373-9

58. CRONSTEIN BN, NAIME D, OSTAD E 1993 The antiinflammatory mechanism of methotrexate. Increased adenosine release at inflamed sites diminishes leukocyte accumulation in an in vivo model of inflammation. J Clin Invest 92: 2675-2682.

https://doi.org/10.1172/JCI116884

59. SABINA RL, KERNSTINE KH, BOYD RL, HOLMES EW, SWAIN JL 1982 Metabolism of 5-amino-4-imidazolecarboxamide riboside in cardiac and skeletal muscle. Effects on purine nucleotide synthesis. J Biol Chem 257: 10178-10183.

https://www.ncbi.nlm.nih.gov/pubmed/7107599

60. SWAIN JL, HINES JJ, SABINA RL, HARBURY OL, HOLMES EW 1984 Disruption of the purine nucleotide cycle by inhibition of adenylosuccinate lyase produces skeletal muscle dysfunction. J Clin Invest 74: 1422-1427. https://doi.org/10.1172/JCI111553

61. MARIE S, HERON B, BITOUN P, TIMMERMAN T, VAN DEN BERGHE G, VINCENT MF 2004 AICA-ribosiduria: a novel, neurologically devastating inborn error of purine biosynthesis caused by mutation of ATIC. Am J Hum Genet 74: 1276-1281. https://doi.org/10.1086/421475

62. LOVE SH, BOYLES PD 1959 Studies on the synthesis of 5-amino-4-imidazolecarboxamide ribotide by cell-free extracts of Escherichia coli. Biochim Biophys Acta 35: 374-380. https://doi.org/10.1016/0006-3002(59)90387-7

63. MORGAN SL, OSTER RA, LEE J Y, ALARCON GS, BAGGOTT JE 2004 The effect of folic acid and folinic acid supplements on purine metabolism in methotrexate-treated rheumatoid arthritis. Arthritis Rheum 50: 3104-3111.

https://doi.org/10.1002/art.20516

64. DIXON R, FUJITAKI J, SANDOVAL T, KISICKI J 1993 Acadesine (AICA-riboside): disposition and metabolism of an adenosine-regulating agent. J Clin Pharmacol 33: 955-958. https://doi.org/10.1002/j.1552-4604.1993.tb01929.x

65. BOCHNER BR, AMES BN 1982 ZTP (5-amino 4-imidazole carboxamide riboside 5'-triphosphate): a proposed alarmone for 10-formyl-tetrahydrofolate deficiency. Cell 29: 929-937. https://doi.org/10.1016/0092-8674(82)90455-x

66. SABINA RL, PATTERSON D, HOLMES EW 1985 5-Amino4-imidazolecarboxamide riboside (Z-riboside) metabolism in eukaryotic cells. J Biol Chem 260: 6107-6114. https://www.ncbi.nlm.nih.gov/pubmed/3997815

67. SIDANI S, KOPIC $S$, SOCRATES T, KIRCHHOFF P, FOLLER M, MUREK M, CAPASSO A, GEIBEL J P 2009 AMP-activated protein kinase: a physiological off switch for murine gastric acid secretion. Pflugers Arch 459: 39-46.

https://doi.org/10.1007/s00424-009-0698-3

68. CHENG XL, ZHOU TY, LI B, LI M Y, LI L, LI Z Q, LU W 2013 Methotrexate and 5-aminoimidazole-4-carboxamide riboside exert synergistic anticancer action against human breast cancer and hepatocellular carcinoma. Acta Pharmacol Sin 34: 951-959. https://doi.org/10.1038/aps.2013.16

69. BAGGOTT JE, MORGAN SL, SAMS WM, LINDEN J 1999 Urinary adenosine and aminoimidazolecarboxamide excretion in methotrexate-treated patients with psoriasis. Arch Dermatol 135: 813-817. https://doi.org/10.1001/archderm.135.7.813
70. SIDI Y, MITCHELL BS 1985 Z-nucleotide accumulation in erythrocytes from Lesch-Nyhan patients. J Clin Invest 76: 24162419. https://doi.org/10.1172/JCI112255

71. COOL B, ZINKER B, CHIOU W, KIFLE L, CAO N, PERHAM M, DICKINSON R, ADLER A, GAGNE G, IYENGAR R, ZHAO G, MARSH K, KYM P, JUNG P, CAMP H S, FREVERT E 2006 Identification and characterization of a small molecule AMPK activator that treats key components of type 2 diabetes and the metabolic syndrome. Cell Metab 3: 403-416. https://doi.org/10.1016/j.cmet.2006.05.005

72. SANDERS MJ, ALI ZS, HEGARTY BD, HEATH R, SNOWDEN MA, CARLING D 2007 Defining the mechanism of activation of AMP-activated protein kinase by the small molecule A-769662, a member of the thienopyridone family. J Biol Chem 282: 32539-32548.

https://doi.org/10.1074/jbc.M706543200

73. XIAO B, SANDERS MJ, CARMENA D, BRIGHT NJ, HAIRE LF, UNDERWOOD E, PATEL BR, HEATH RB, WALKER PA, HALLEN S, GIORDANETTO F, MARTIN SR, CARLING D, GAMBLIN SJ 2013 Structural basis of AMPK regulation by small molecule activators. Nat Commun 4: 3017.

https://doi.org/10.1038/ncomms4017

74. MYERS RW, GUAN HP, EHRHART J, PETROV A, PRAHALADA S, TOZZO E, YANG X, KURTZ MM, TRUJILLO M, GONZALEZ TROTTER D, FENG D, XU S, EIERMANN G, HOLAHAN MA, RUBINS D, CONARELLO S, NIU X, SOUZA S C, MILLER C, LIU J, LU K, FENG W, LI Y, PAINTER RE, MILLIGAN JA, HE H, LIU F, OGAWAA, WISNIEWS KI D, ROHM RJ, WANG L, BUNZEL M, QIAN Y, ZHU W, WANG H, BENNET B, LAFRANCO SCHEUCH L, FERNANDEZ GE, LI C, KLIMAS M, ZHOU G, VAN HEEK M, BIFTU T, WEBER A, KELLEY DE, THORNBERRY N, ERION MD, KEMP D M, SEBHAT IK 2017 Systemic pan-AMPK activator MK-8722 improves glucose homeostasis but induces cardiac hypertrophy. Science 357: 507-511.

https://doi.org/10.1126/science.aah5582

75. COKORINOS EC, DELMORE J, REYES AR, ALBUQUERQUE B, KJOBSTED R, JORGENSEN NO, TRAN JL, JATKAR A, CIALDEA K, ESQUEJO RM, MEISSEN J, CALABRESE MF, CORDES J, MOCCIA R, TESS D, SALATTO CT, COSKRAN TM, OPSAHL AC, FLYNN D, BLATNIK M, LI W, KINDT E, FORETZ M, VIOLLET B, WARD J, KURUMBAIL RG, KALGUTKAR AS, WOJTASZEWSKI JFP, CAMERON KO, MILLER RA 2017 Activation of Skeletal Muscle AMPK promotes glucose disposal and glucose lowering in non-human primates and mice. Cell Metab 25: 1147-1159 e1110.

https://doi.org/10.1016/j.cmet.2017.04.010

76. ZHOU G, MYERS R, LI Y, CHEN Y, SHEN X, FENYK-MELODY J, WU M, VENTRE J, DOEBBER T, FUJII N, MUSI N, HIRSHMAN MF, GOODYEAR LJ, MOLLER DE 2001 Role of AMP-activated protein kinase in mechanism of metformin action. J Clin Invest 108: 1167-1174. https://doi.org/10.1172/JCI13505

77. OWEN MR, DORAN E, HALESTRAP AP 2000 Evidence that metformin exerts its anti-diabetic effects through inhibition of complex 1 of the mitochondrial respiratory chain. Biochem J 348 (Pt 3): 607-614. https://www.ncbi.nlm.nih.gov/pubmed/10839993

78. EL-MIR MY, NOGUEIRA V, FONTAINE E, AVERET N, RIGOULET M, LEVERVE X 2000 Dimethylbiguanide inhibits cell respiration via an indirect effect targeted on the respiratory chain complex I. J Biol Chem 275: 223-228.

https://doi.org/10.1074/jbc.275.1.223

79. HAWLEY SA, FORD RJ, SMITH BK, GOWANS GJ, MANCINI SJ, PITT RD, DAY EA, SALT IP, STEINBERG GR, HARDIE DG 2016 The $\mathrm{Na}^{+} /$glucose cotransporter inhibitor canagliflozin activates AMPK by inhibiting mitochondrial function and increasing cellular AMP levels. Diabetes 65: 2784-2794. https://doi.org/10.2337/db16-0058 
80. VILLANI LA, SMITH BK, MARCINKO K, FORD R J, BROADFIELD LA, GREEN AE, HOUDE VP, MUTI P, TSAKIRIDIS T, STEINBERG GR 2016 The diabetes medication Canagliflozin reduces cancer cell proliferation by inhibiting mitochondrial complex-I supported respiration. Mol Metab 5: 1048 1056. https://doi.org/10.1016/j.molmet.2016.08.014

81. SMITH BK, FORD RJ, DESJARDINS EM, GREEN AE, HUGHES MC, HOUDE VP, DAY EA, MARCINKO K, CRANE JD, MOTTILLO EP, PERRY CG, KEMP BE, TARNOPOLSKY MA, STEINBERG GR 2016 Salsalate (Salicylate) uncouples mitochondria, improves glucose homeostasis, and reduces liver lipids independent of AMPK-beta1. Diabetes 65: 33523361. https://doi.org/10.2337/db16-0564

82. BERGERON R, RUSSELL $3^{\text {rd }}$ RR, YOUNG LH, REN JM, MARCUCCI M, LEE A, SHULMAN GI 1999 Effect of AMPK activation on muscle glucose metabolism in conscious rats. Am J Physiol 276: E938-944.

https://doi.org/10.1152/ajpendo.1999.276.5.E938

83. KAUSHIK VK, YOUNG ME, DEAN DJ, KUROWSKI TG, SAHA AK, RUDERMAN NB 2001 Regulation of fatty acid oxidation and glucose metabolism in rat soleus muscle: effects of AICAR. Am J Physiol Endocrinol Metab 281: E335-340. https://doi.org/10.1152/ajpendo.2001.281.2.E335

84. WINDER WW, WILSON HA, HARDIE DG, RASMUSSEN BB, HUTBER CA, CALL GB, CLAYTON RD, CONLEY LM, YOON S, ZHOU B 1997 Phosphorylation of rat muscle acetylCoA carboxylase by AMP-activated protein kinase and protein kinase A. J Appl Physiol (1985) 82: 219-225. https://doi.org/10.1152/jappl.1997.82.1.219

85. AI H, IHLEMANN J, HELLSTEN Y, LAURITZEN HP, HARDIE DG, GALBO H, PLOUG T 2002 Effect of fiber type and nutritional state on AICAR- and contraction-stimulated glucose transport in rat muscle. Am J Physiol Endocrinol Metab 282: E1291-1300. https://doi.org/10.1152/ajpendo.00167.2001

86. BERGERON R, PREVIS SF, CLINE GW, PERRET P, RUSSELI $3^{\text {rd }}$ RR, YOUNG LH, SHULMAN GI 2001 Effect of 5-aminoimidazole-4-carboxamide-1-beta-D-ribofuranoside infusion on in vivo glucose and lipid metabolism in lean and obese Zucker rats. Diabetes 50: 1076-1082. https://doi.org/10.2337/diabetes.50.5.1076

87. KOISTINEN HA, GALUSKA D, CHIBALIN AV, YANG J, ZIERATH JR, HOLMAN GD, WALLBERG-HENRIKSSON H 2003 5-amino-imidazole carboxamide riboside increases glucose transport and cell-surface GLUT4 content in skeletal muscle from subjects with type 2 diabetes. Diabetes 52: 1066-1072. https://doi.org/10.2337/diabetes.52.5.1066

88. BOON H, BOSSELAAR M, PRAET SF, BLAAK EE, SARIS WH, WAGENMAKERS AJ, MCGEE SL, TACK CJ, SMITS P, HARGREAVES M, VAN LOON LJ 2008 Intravenous AICAR administration reduces hepatic glucose output and inhibits whole body lipolysis in type 2 diabetic patients. Diabetologia 51: 1893 1900. https://doi.org/10.1007/s00125-008-1108-7

89. SONG XM, FIEDLER M, GALUSKA D, RYDER JW, FERNSTROM M, CHIBALIN AV, WALLBERG-HENRIKSSON H, ZIERATH JR 2002 5-Aminoimidazole-4-carboxamide ribonucleoside treatment improves glucose homeostasis in insulin-resistant diabetic (ob/ob) mice. Diabetologia 45: 56-65. https://doi.org/10.1007/s001250200006

90. KJOBSTED R, MUNK-HANSEN N, BIRK JB, FORETZ M, VIOLLET B, BJORNHOLM M, ZIERATH JR, TREEBAK JT, WOJTASZEWSKI JF 2017 Enhanced Muscle Insulin Sensitivity After Contraction/Exercise Is Mediated by AMPK. Diabetes 66: 598-612. https://doi.org/10.2337/db16-0530

91. FOGARTYS, HARDIE DG 2010 Development of protein kinase activators: AMPK as a target in metabolic disorders and cancer. Biochim Biophys Acta 1804: 581-591. https://doi.org/10.1016/j.bbapap.2009.09.012
92. VINCENT MF, MARANGOS PJ, GRUBER HE, VAN DEN BERGHE G 1991 Inhibition by AICA riboside of gluconeogenesis in isolated rat hepatocytes. Diabetes 40: 1259-1266. https://doi.org/10.2337/diab.40.10.1259

93. LONGNUS SL, WAMBOLT RB, PARSONS HL, BROWNSEY RW, ALLARD MF 2003 5-Aminoimidazole-4-carboxamide 1-beta -D-ribofuranoside (AICAR) stimulates myocardial glycogenolysis by allosteric mechanisms. Am J Physiol Regul Integr Comp Physiol 284: R936-944. https://doi.org/10.1152/ajpregu.00319.2002

94. CUTHBERTSON DJ, BABRAJ JA, MUSTARD KJ, TOWLER MC, GREEN KA, WACKERHAGE H, LEESE GP, BAAR K, THOMASON-HUGHES M, SUTHERLAND C, HARDIE DG, RENNIE MJ 2007 5-aminoimidazole-4-carboxamide 1-beta-D-ribofuranoside acutely stimulates skeletal muscle 2-deoxyglucose uptake in healthy men. Diabetes 56: 2078-2084. https://doi.org/10.2337/db06-1716

95. BENZIANE B, BJORNHOLM M, LANTIER L, VIOLLET B, ZIERATH JR, CHIBALIN AV 2009 AMP-activated protein kinase activator A-769662 is an inhibitor of the $\mathrm{Na}(+)-\mathrm{K}(+)$ ATPase. Am J Physiol Cell Physiol 297: C1554-1566. https://doi.org/10.1152/ajpcell.00010.2009

96. PERDAN-PIRKMAJER K, PIRKMAJER S, THEVIS M, THOMAS A, PRAPROTNIK S, HOCEVAR A, ROTAR Z, GASPERSIC N, SODIN-SEMRL S, ZIBERT J, OMERSEL J, CHIBALIN AV, TOMSIC M, AMBROZIC A 2016 Methotrexate reduces $\mathrm{HbAlc}$ concentration but does not produce chronic accumulation of ZMP in patients with rheumatoid or psoriatic arthritis. Scand J Rheumatol 45: 347-355. https://doi.org/10.3109/03009742.2015.1105290

97. PIPER T, THOMAS A, BAUME N, SOBOLEVSKYT, SAUGY M, RODCHENKOV G, SCHANZER W, THEVIS M 2014 Determination of (1)(3)C/(1)(2) C ratios of endogenous urinary 5-amino-imidazole-4-carboxamide 1beta-D-ribofuranoside (AICAR). Rapid Commun Mass Spectrom 28: 1194-1202. https://doi.org/10.1002/rcm.6891

98. THOMAS A, VOGEL M, PIPER T, KRUG O, BEUCK $S$, SCHANZER W, THEVIS M 2013 Quantification of AICARribotide concentrations in red blood cells by means of LC-MS/ MS. Anal Bioanal Chem 405: 9703-9709. https://doi.org/10.1007/s00216-013-7162-0

99. THOMAS A, BEUCK S, EICKHOFF J C, GUDDAT S, KRUG O, KAMBER M, SCHANZER W, THEVIS M 2010 Quantification of urinary AICAR concentrations as a matter of doping controls. Anal Bioanal Chem 396: 2899-2908. https://doi.org/10.1007/s00216-010-3560-8

100. GREENBERG GR, SPILMAN EL 1956 Isolation of 5-amino4-imidazolecarboxamide riboside. J Biol Chem 219: 411-422. https://www.ncbi.nlm.nih.gov/pubmed/13295295

101. GREENBERG GR 1956 Preparation of 5'-phosphoribosyl-5-amino-4-imidazole-carboxamide. J Biol Chem 219: 423-433. https://www.ncbi.nlm.nih.gov/pubmed/13295296

102. CAMPAS C, LOPEZ JM, SANTIDRIAN AF, BARRAGAN M, BELLOSILLO B, COLOMER D, GIL J 2003 Acadesine activates AMPK and induces apoptosis in B-cell chronic lymphocytic leukemia cells but not in T lymphocytes. Blood 101: 3674 3680. https://doi.org/10.1182/blood-2002-07-2339

103. GADALLA AE, PEARSON T, CURRIE AJ, DALE N, HAWLEY SA, SHEEHAN M, HIRST W, MICHEL AD, RANDALL A, HARDIE DG, FRENGUELLI BG 2004 AICA riboside both activates AMP-activated protein kinase and competes with adenosine for the nucleoside transporter in the CA1 region of the rat hippocampus. J Neurochem 88: 1272-1282. https://doi.org/10.1046/j.1471-4159.2003.02253.x

104. DOLINAR K, JAN V, PAVLIN M, CHIBALIN AV, PIRKMAJER S 2018 Nucleosides block AICAR-stimulated activation of 
AMPK in skeletal muscle and cancer cells. Am J Physiol Cell Physiol https://doi.org/10.1152/ajpcell.00311.2017

105. CESCHIN J, SAINT-MARC C, LAPORTE J, LABRIET A, PHILIPPE C, MOENNER M, DAIGNAN-FORNIER B, PINSON B 2014 Identification of yeast and human 5-aminoimidazole-4-carboxamide-1-beta-d-ribofuranoside (AICAr) transporters. J Biol Chem 289: 16844-16854. https://doi.org/10.1074/jbc.M114.551192

106. FLAKS JG, ERWIN MJ, BUCHANAN JM 1957 Biosynthesis of the purines. XVI. The synthesis of adenosine 5'-phosphate and 5-amino-4-imidazolecarboxamide ribotide by a nucleotide pyrophosphorylase. J Biol Chem 228: 201-213.

https://www.ncbi.nlm.nih.gov/pubmed/13475309

107. VINCENT MF, BONTEMPS F, VAN DEN BERGHE G 1996 Substrate cycling between 5-amino-4-imidazolecarboxamide riboside and its monophosphate in isolated rat hepatocytes. Biochem Pharmacol 52: 999-1006.

https://doi.org/10.1016/0006-2952(96)00413-3

108. SABINA RL, HOLMES EW, BECKER MA 1984 The enzymatic synthesis of 5-amino-4-imidazolecarboxamide riboside triphosphate (ZTP). Science 223: 1193-1195. https://doi.org/10.1126/science.6199843

109. MCGEER PL, MCGEER EG, WOOD AJ 1961 Excretion of 4-amino-5-imidazolecarboxamide by various animal species. Can J Comp Med Vet Sci 25: 211-212. https://www.ncbi.nlm.nih.gov/pubmed/17649319

110. FLAKS JG, ERWIN MJ, BUCHANAN JM 1957 Biosynthesis of the purines. XVIII. 5-Amino-1-ribosyl-4-imidazolecarboxamide 5'-phosphate transformylase and inosinicase. J Biol Chem 229: 603-612. https://www.ncbi.nlm.nih.gov/pubmed/13502325

111. HARTMAN SC, BUCHANAN JM 1959 Biosynthesis of the purines. XXVI. The identification of the formyl donors of the transformylation reactions. J Biol Chem 234: 1812-1816. https://www.ncbi.nlm.nih.gov/pubmed/13672969

112. NI L, GUAN K, ZALKIN H, DIXON JE 1991 De novo purine nucleotide biosynthesis: cloning, sequencing and expression of a chicken PurH cDNA encoding 5-aminoimidazole-4-carboxamide-ribonucleotide transformylase-IMP cyclohydrolase. Gene 106: 197-205. https://doi.org/10.1016/0378-1119(91)90199-1

113. YAMAUCHI M, SEKI N, MITA K, SAITO T, TSUJI S, HONGO E, MORIMYO M, SHIOMI T, KOYAMA H, AYUSAWA D 1995 Isolation of human purH gene expressed in the rodent transformant cells by subtractive enrichment of 3'-untranslated region of human transcript. DNA Res 2: 269-275.

https://doi.org/10.1093/dnares/2.6.269

114. RAYLEA, MOROSON BA, BEARDSLEY GP 1996 The human purH gene product, 5-aminoimidazole-4-carboxamide ribonucleotide formyltransferase/IMP cyclohydrolase. Cloning, sequencing, expression, purification, kinetic analysis, and domain mapping. J Biol Chem 271: 2225-2233.

https://doi.org/10.1074/jbc.271.4.2225

115. SUGITA T, AYA H, UENO M, ISHIZUKA T, KAWASHIMA K 1997 Characterization of molecularly cloned human 5-aminoimidazole-4-carboxamide ribonucleotide transformylase. J Biochem 122: 309-313.

https://doi.org/10.1093/oxfordjournals.jbchem.a021754

116. GREASLEYSE, HORTON P, RAMCHARAN J, BEARDSLEY GP, BENKOVIC SJ, WILSON IA 2001 Crystal structure of a bifunctional transformylase and cyclohydrolase enzyme in purine biosynthesis. Nat Struct Biol 8: 402-406.

https://doi.org/10.1038/87555

117. CHEONG CG, WOLAN DW, GREASLEY SE, HORTON PA, BEARDSLEY GP, WILSON IA 2004 Crystal structures of human bifunctional enzyme aminoimidazole-4-carboxamide ribonucleotide transformylase/IMP cyclohydrolase in complex with potent sulfonyl-containing antifolates. J Biol Chem 279: $18034-$ 18045. https://doi.org/10.1074/jbc.M313691200

118. XU L, CHONG Y, HWANG I, D’ONOFRIO A, AMORE K, BEARDSLEY G P, LI C, OLSON AJ, BOGER DL, WILSON IA 2007 Structure-based design, synthesis, evaluation, and crystal structures of transition state analogue inhibitors of inosine monophosphate cyclohydrolase. J Biol Chem 282: 13033-13046. https://doi.org/10.1074/jbc.M607293200

119. XU L, LI C, OLSON AJ, WILSON IA 2004 Crystal structure of avian aminoimidazole-4-carboxamide ribonucleotide transformylase in complex with a novel non-folate inhibitor identified by virtual ligand screening. J Biol Chem 279: 50555-50565. https://doi.org/10.1074/jbc.M406801200

120. WOLAN DW, GREASLEY SE, BEARDSLEY GP, WILSON IA 2002 Structural insights into the avian AICAR transformylase mechanism. Biochemistry 41: 15505-15513. https://doi.org/10.1021/bi020505x

121. WOLAN DW, CHEONG CG, GREASLEY SE, WILSON IA 2004 Structural insights into the human and avian IMP cyclohydrolase mechanism via crystal structures with the bound XMP inhibitor. Biochemistry 43: 1171-1183.

https://doi.org/10.1021/bi030162i

122. GADANGI P, LONGAKER M, NAIME D, LEVIN R I, RECHT PA, MONTESINOS MC, BUCKLEY MT, CARLIN G, CRONSTEIN BN 1996 The anti-inflammatory mechanism of sulfasalazine is related to adenosine release at inflamed sites. J Immunol 156: 1937-1941.

https://www.ncbi.nlm.nih.gov/pubmed/8596047

123. BARESOVA V, SKOPOVA V, SIKORA J, PATTERSON D, SOVOVA J, ZIKANOVA M, KMOCH S 2012 Mutations of ATIC and ADSL affect purinosome assembly in cultured skin fibroblasts from patients with AICA-ribosiduria and ADSL deficiency. Hum Mol Genet 21: 1534-1543.

https://doi.org/10.1093/hmg/ddr591

124. BONSDORFF T, GAUTIER M, FARSTAD W, RONNINGEN K, LINGAAS F, OLSAKER I 2004 Mapping of the bovine genes of the de novo AMP synthesis pathway. Anim Genet 35: 438444. https://doi.org/10.1111/j.1365-2052.2004.01201.x

125. BROSH S, BOER P, ZOREF-SHANI E, SPERLING O 1982 De novo purine synthesis in skeletal muscle. Biochim Biophys Acta 714: 181-183. https://doi.org/10.1016/0304-4165(82)90143-x

126. ZOREF-SHANI E, SHAINBERG A, SPERLING O 1982 Characterization of purine nucleotide metabolism in primary rat muscle cultures. Biochim Biophys Acta 716: 324-330. https://doi.org/10.1016/0304-4165(82)90023-x

127. ZOREF-SHANI E, SHAINBERG A, SPERLING O 1987 Pathways of adenine nucleotide catabolism in primary rat muscle cultures. Biochim Biophys Acta 926: 287-295. https://doi.org/10.1016/0304-4165(87)90215-7

128. ZOREF-SHANI E, SHAINBERG A, SPERLING O 1983 Alterations in purine nucleotide metabolism during muscle differentiation in vitro. Biochem Biophys Res Commun 116: 507-512. https://doi.org/10.1016/0006-291x(83)90552-1

129. SHEEHAN TG, TULLY ER 1983 Purine biosynthesis de novo in rat skeletal muscle. Biochem J 216: 605-610. https://doi.org/10.1042/bj2160605

130. NATSUMEDA Y, PRAJDA N, DONOHUE JP, GLOVER JL, WEBER G 1984 Enzymic capacities of purine de novo and salvage pathways for nucleotide synthesis in normal and neoplastic tissues. Cancer Res 44: 2475-2479. https://www.ncbi.nlm.nih.gov/pubmed/6327016

131. TULLSON PC, JOHN-ALDER HB, HOOD DA, TERJUNG RL 1988 De novo synthesis of adenine nucleotides in different 
skeletal muscle fiber types. Am J Physiol 255: C271-277.

https://doi.org/10.1152/ajpcell.1988.255.3.C271

132. BRAULT JJ, TERJUNG RL 2001 Purine salvage to adenine nucleotides in different skeletal muscle fiber types. J Appl Physiol (1985) 91: 231-238. https://doi.org/10.1152/jappl.2001.91.1.231

133. HELLSTEN Y, RICHTER EA, KIENS B, BANGSBO J 1999 AMP deamination and purine exchange in human skeletal muscle during and after intense exercise. J Physiol 520 Pt 3: 909-920. https://doi.org/10.1111/j.1469-7793.1999.00909.x

134. BERTRAND R, JOLIVET J 1989 Methenyltetrahydrofolate synthetase prevents the inhibition of phosphoribosyl 5-aminoimidazole 4-carboxamide ribonucleotide formyltransferase by 5 -formyltetrahydrofolate polyglutamates. J Biol Chem 264: 8843-8846. https://www.ncbi.nlm.nih.gov/pubmed/2470749

135. CRONSTEIN BN 1995 The antirheumatic agents sulphasalazine and methotrexate share an anti-inflammatory mechanism. $\mathrm{Br} \mathrm{J}$ Rheumatol 34 Suppl 2: 30-32. https://www.ncbi.nlm.nih.gov/pubmed/8535646

136. MORABITO L, MONTESINOS MC, SCHREIBMAN DM, BALTER L, THOMPSON LF, RESTA R, CARLIN G, HUIE MA, CRONSTEIN BN 1998 Methotrexate and sulfasalazine promote adenosine release by a mechanism that requires ecto- 5 ' nucleotidase-mediated conversion of adenine nucleotides. J Clin Invest 101: 295-300. https://doi.org/10.1172/JCI1554

137. LULENSKI G, DONALDSON M, NEWCOMBE D 1970 Urinary aminoimidazolecarboxamide levels in children with acute leukemia. Pediatrics 45: 983-995.

https://www.ncbi.nlm.nih.gov/pubmed/5268251

138. LUHBY AL, COOPERMAN JM 1962 Aminoimidazolecarboxamide excretion in vitamin-B12 and folic-acid deficiencies. Lancet 2: 1381-1382. https://doi.org/10.1016/s0140-6736(62)91051-6

139. ALLEGRA CJ, FINE RL, DRAKE JC, CHABNER BA 1986 The effect of methotrexate on intracellular folate pools in human MCF-7 breast cancer cells. Evidence for direct inhibition of purine synthesis. J Biol Chem 261: 6478-6485.

https://www.ncbi.nlm.nih.gov/pubmed/3700401

140. BOKKERINK JP, BAKKER MA, HULSCHER TW, DE ABREU RA, SCHRETLEN ED 1988 Purine de novo synthesis as the basis of synergism of methotrexate and 6-mercaptopurine in human malignant lymphoblasts of different lineages. Biochem Pharmacol 37: 2321-2327.

https://doi.org/10.1016/0006-2952(88)90358-9

141. SHOLAR PW, BARAM J, SEITHER R, ALLEGRA CJ 1988 Inhibition of folate-dependent enzymes by 7-OH-methotrexate. Biochem Pharmacol 37: 3531-3534. https://doi.org/10.1016/0006-2952(88)90709-5

142. BAGGOTT JE, MORGAN SL, VAUGHN WH 1994 Differences in methotrexate and 7-hydroxymethotrexate inhibition of folate-dependent enzymes of purine nucleotide biosynthesis. Biochem J 300 ( Pt 3): 627-629. https://doi.org/10.1042/bj3000627

143. HA T, MORGAN SL, VAUGHN WH, ETO I, BAGGOTT JE 1990 Detection of inhibition of 5-aminoimidazole-4-carboxamide ribotide transformylase by thioinosinic acid and azathioprine by a new colorimetric assay. Biochem J 272: 339-342. https://doi.org/10.1042/bj2720339

144. SVENSON KL, POLLARE T, LITHELL H, HALLGREN R 1988 Impaired glucose handling in active rheumatoid arthritis: relationship to peripheral insulin resistance. Metabolism 37: 125-130. https://doi.org/10.1016/s0026-0495(98)90005-1

145. REKEDAL LR, MASSAROTTI E, GARG R, BHATIA R, GLEESON T, LU B, SOLOMON DH 2010 Changes in glycosylated hemoglobin after initiation of hydroxychloroquine or methotrexate treatment in diabetes patients with rheumatic diseases. Arthritis Rheum 62: 3569-3573. https://doi.org/10.1002/art.27703
146. SMOLEN JS, LANDEWE R, BIJLSMA J, BURMESTER G, CHATZIDIONYSIOU K, DOUGADOS M, NAM J, RAMIRO $S$, VOSHAAR M, VAN VOLLENHOVEN R, ALETAHA D, ARINGER M, BOERS M, BUCKLEY CD, BUTTGEREIT F, BYKERK V, CARDIEL M, COMBE B, CUTOLO M, VAN EIJK-HUSTINGS Y, EMERY P, FINCKH A, GABAY C, GOMEZ-REINO J, GOSSEC L, GOTTENBERG JE, HAZES JMW, HUIZINGA T, JANI M, KARATEEV D, KOULOUMAS M, KVIEN T, LI Z, MARIETTE X, MCINNES I, MYSLER E, NASH P, PAVELKA K, POOR G, RICHEZ C, VAN RIEL P, RUBBERT-ROTH A, SAAG K, DA SILVA J, STAMM T, TAKEUCHI T, WESTHOVENS R, DE WIT M, VAN DER HEIJDE D 2017 EULAR recommendations for the management of rheumatoid arthritis with synthetic and biological disease-modifying antirheumatic drugs: 2016 update. Ann Rheum Dis 76: 960-977. https://doi.org/10.1136/annrheumdis-2016-210715

147. ALETAHA D, SMOLEN JS 2018 Diagnosis and management of rheumatoid arthritis: a review. JAMA 320: 1360-1372. https://doi.org/10.1001/jama.2018.13103

148. RASK-MADSEN C, DOMINGUEZ H, IHLEMANN N, HERMANN T, KOBER L, TORP-PEDERSEN C 2003 Tumor necrosis factor-alpha inhibits insulin's stimulating effect on glucose uptake and endothelium-dependent vasodilation in humans. Circulation 108: 1815-1821 https://doi.org/10.1161/01.CIR.0000091406.72832.11

149. PLOMGAARD P, BOUZAKRI K, KROGH-MADSEN R, MITTENDORFER B, ZIERATH JR, PEDERSEN B K 2005 Tumor necrosis factor-alpha induces skeletal muscle insulin resistance in healthy human subjects via inhibition of Akt substrate 160 phosphorylation. Diabetes 54: 2939-2945. https://doi.org/10.2337/diabetes.54.10.2939

150. YAO X, YE F, ZHANG M, CUI C, HUANG B, NIU P, LIU X, ZHAO L, DONG E, SONG C, ZHAN S, LU R, LI H, TAN W, LIU D 2020 In vitro antiviral activity and projection of optimized dosing design of hydroxychloroquine for the treatment of severe acute respiratory syndrome coronavirus 2 (SARS-CoV-2). Clin Infect Dis ciaa237. https://doi.org/10.1093/cid/ciaa237

151. LIU J, CAO R, XU M, WANG X, ZHANG H, HU H, LI Y, HU Z, ZHONG W, WANG M 2020 Hydroxychloroquine, a less toxic derivative of chloroquine, is effective in inhibiting SARSCoV-2 infection in vitro. Cell Discov 6: 16. https://doi.org/10.1038/s41421-020-0156-0

152. BOULWARE DR, PULLEN MF, BANGDIWALA AS, PAS TICK KA, LOFGREN SM, OKAFOR EC, SKIPPER CP, NASCENE AA, NICOL MR, ABASSI M, ENGEN NW, CHENG MP, LABAR D, LOTHER S A, MACKENZIE LJ, DROBOT G, MARTEN N, ZARYCHANSKI R, KELLY LE, SCHWARTZ IS, MCDONALD EG, RAJASINGHAM R, LEE TC, HULLSIEK KH 2020 A randomized trial of hydroxychloroquine as postexposure prophylaxis for Covid-19. N Engl J Med https://doi.org/10.1056/NEJMoa2016638

153. LOTHER SA, ABASSI M, AGOSTINIS A, BANGDIWALA AS, CHENG MP, DROBOT G, ENGEN N, HULLSIEK KH, KELLY LE, LEE TC, LOFGREN SM, MACKENZIE LJ, MARTEN N, MCDONALD EG, OKAFOR EC, PASTICK KA, PULLEN MF, RAJASINGHAM R, SCHWARTZ I, SKIPPER CP, TURGEON AF, ZARYCHANSKI R, BOULWARE DR 2020 Post-exposure prophylaxis or pre-emptive therapy for severe acute respiratory syndrome coronavirus 2 (SARS-CoV-2): study protocol for a pragmatic randomized-controlled trial. Can J Anaesth https://doi.org/10.1007/s12630-020-01684-7

154. PASTICK KA, OKAFOR EC, WANG F, LOFGREN SM SKIPPER CP, NICOL MR, PULLEN MF, RAJASINGHAM R, MCDONALD EG, LEE TC, SCHWARTZ IS, KELLY LE, LOTHER SA, MITJA O, LETANG E, ABASSI M, BOULWARE DR 2020 Review: hydroxychloroquine and chloroquine 
for treatment of SARS-CoV-2 (COVID-19). Open Forum Infect Dis 7: ofaa130. https://doi.org/10.1093/ofid/ofaa130

155. GELERIS J, SUN Y, PLATT J, ZUCKER J, BALDWIN M, HRIPCSAK G, LABELLA A, MANSON D, KUBIN C, BARR RG, SOBIESZCZYK ME, SCHLUGER NW 2020 Observational study of hydroxychloroquine in hospitalized patients with Covid-19. N Engl J Med 82:2411-2418. https://doi.org/10.1056/NEJMoa2012410

156. MEHRA MR, RUSCHITZKA F, PATEL AN 2020 Retraction: Hydroxychloroquine or chloroquine with or without a macrolide for treatment of COVID-19: a multinational registry analysis. Lancet https://doi.org/10.1016/S0140-6736(20)31324-6

157. MEHRA MR, DESAI SS, RUSCHITZKA F, PATEL AN 2020 Retracted: Hydroxychloroquine or chloroquine with or without a macrolide for treatment of COVID-19: a multinational registry analysis. Lancet https://doi.org/10.1016/S0140-6736(20)31180-6

158. REMPENAULT C, COMBE B, BARNETCHE T, GAUJOUXVIALA C, LUKAS C, MOREL J, HUA C 2018 Metabolic and cardiovascular benefits of hydroxychloroquine in patients with rheumatoid arthritis: a systematic review and meta-analysis. Ann Rheum Dis 77: 98-103.

https://doi.org/10.1136/annrheumdis-2017-211836

159. SCHREZENMEIER E, DORNER T 2020 Mechanisms of action of hydroxychloroquine and chloroquine: implications for rheumatology. Nat Rev Rheumatol 16: 155-166. https://doi.org/10.1038/s41584-020-0372-x

160. THIERSCH JB 1949 Bone-marrow changes in man after treatment with aminopterin, amethopterin, and aminoanfol: With special reference to megaloblastosis and tumor remission. Cancer 2 : $877-883$.

https://doi.org/10.1002/1097-0142(194909)2:5<877::AIDCNCR2820020520>3.0.CO;2-0

161. CREWS KR, LIU T, RODRIGUEZ-GALINDO C, TAN M, MEYER WH, PANETTA JC, LINK MP, DAW NC 2004 Highdose methotrexate pharmacokinetics and outcome of children and young adults with osteosarcoma. Cancer 100: 1724-1733. https://doi.org/10.1002/cncr.20152

162. WEINBLATT ME, COBLYN JS, FOX DA, FRASER PA, HOLDSWORTH DE, GLASS DN, TRENTHAM DE 1985 Efficacy of low-dose methotrexate in rheumatoid arthritis. N Engl J Med 312: 818-822. https://doi.org/10.1056/NEJM198503283121303

163. COMBE B, EDNO L, LAFFORGUE P, BOLOGNA C, BERNARD JC, ACQUAVIVA P, SANY J, BRESSOLLE F 1995 Total and free methotrexate pharmacokinetics, with and without piroxicam, in rheumatoid arthritis patients. Br J Rheumatol 34: 421-428. http://www.ncbi.nlm.nih.gov/pubmed/7788170

164. CHLADEK J, SIMKOVA M, VANECKOVA J, HROCH M, CHLADKOVA J, MARTINKOVA J, VAVROVA J, BERANEK M 2008 The effect of folic acid supplementation on the pharmacokinetics and pharmacodynamics of oral methotrexate during the remission-induction period of treatment for moderate-to-severe plaque psoriasis. Eur J Clin Pharmacol 64: 347-355. https://doi.org/10.1007/s00228-007-0442-x

165. HIRAGA Y, YUHKI Y, ITOH K, TADANO K, TAKAHASHI Y, MUKAI M 2004 Pharmacokinetics and efficacy of low-dose methotrexate in patients with rheumatoid arthritis. Mod Rheumatol 14: 135-142. https://doi.org/10.1007/s10165-004-0280-y

166. CRONSTEIN BN, EBERLE MA, GRUBER HE, LEVIN RI 1991 Methotrexate inhibits neutrophil function by stimulating adenosine release from connective tissue cells. Proc Natl Acad Sci USA 88: 2441-2445. https://doi.org/10.1073/pnas.88.6.2441

167. ZHENG L, HOWELL SJ, HATALA DA, HUANG K, KERN TS 2007 Salicylate-based anti-inflammatory drugs inhibit the early lesion of diabetic retinopathy. Diabetes 56: 337-345. https://doi.org/10.2337/db06-0789
168. BERTI-MATTERA LN, KERN T S, SIEGEL RE, NEMET I, MITCHELL R 2008 Sulfasalazine blocks the development of tactile allodynia in diabetic rats. Diabetes 57: 2801-2808. https://doi.org/10.2337/db07-1274

169. HAAS RM, LI P, CHU J W 2005 Glucose-lowering effects of sulfasalazine in type 2 diabetes. Diabetes Care 28: 2238-2239. https://doi.org/10.2337/diacare.28.9.2238

170. LEMBERG A, DAUNAS JA, BRODOFF BB, PENHOS JC, SODERO EC, WHITE R 1967 Action of methotrexate on metabolism of lipids and carbohydrates of the perfused isolated liver. Cancer 20: 1668-1672. https://www.ncbi.nlm.nih.gov/pubmed/6058175

171. DE OLIVEIRA MB, ISHII EL, YAMAMOTO NS, BRACHT AM, CAMPELLO ADE P, KLUPPEL ML, BRACHT A 1986 Methotrexate increases glycogenolysis in the intact rat liver. Res Commun Chem Pathol Pharmacol 53: 173-181. https://www.ncbi.nlm.nih.gov/pubmed/3764081

172. TOMS TE, PANOULAS VF, JOHN H, DOUGLAS KM, KITAS GD 2009 Methotrexate therapy associates with reduced prevalence of the metabolic syndrome in rheumatoid arthritis patients over the age of 60- more than just an anti-inflammatory effect? A cross sectional study. Arthritis Res Ther 11: R110. https://doi.org/10.1186/ar2765

173. DEOLIVEIRA CC, ACEDO SC, GOTARDO EM, CARVALHO PDE O, ROCHA T, PEDRAZZOLI Jr J, GAMBERO A 2012 Effects of methotrexate on inflammatory alterations induced by obesity: an in vivo and in vitro study. Mol Cell Endocrinol 361: 92-98. https://doi.org/10.1016/j.mce.2012.03.016

174. RUSSO GT, MINUTOLI L, BITTO A, ALTAVILLA D, ALESSI E, GIANDALIA A, ROMEO EL, STAGNO MF, SQUADRITO F, CUCINOTTA D, SELHUB J 2012 Methotrexate increases skeletal muscle GLUT4 expression and improves metabolic control in experimental diabetes. J Nutr Metab 2012: 132056. https://doi.org/10.1155/2012/132056

175. GERASIMOVA EV, POPKOVA TV, NOVIKOVA DS, NASONOV EL 2014 Cardiovascular diseases in patients with rheumatoid arthritis during long-term methotrexate therapy [Article in Russian]. Ter Arkh 86: 26-31. https://www.ncbi.nlm.nih.gov/pubmed/25026799

176. DEHPOURI T, ROKNI GR, NARENJBON NA, GOLDUST M, YAMAUCHI PS, WOLLINA U, LOTTI T, KIRCIK L, LERNIA VGD, SONTHALIA S, VOJVODIC A, SZEPIETOWSKI J, BAHADORAN P, ERRICHETTI E, CANTISANI C, ATZORI L, REZAEE E, KUTLUBAY Z, ENGIN B, NISTICÒ S, DAMIANI G, CONIC RRZ, GOREN A, ČABRIJAN L, TCHERNEV G 2019 Evaluation of the glycemic effect of methotrexate in psoriatic arthritis patients with metabolic syndrome: A pilot study. Dermatol Reports 11: 7965.

https://doi.org/10.4081/dr.2019.7965

177. GERSHBEIN LL, MILLER A, AL-WATTAR J 1964 Effect of Water-soluble vitamins on rat diaphragm carbohydrate metabolism. Arch Biochem Biophys 107: 359-362. https://doi.org/10.1016/0003-9861(64)90290-5

178. MOTAWI TMK, BUSTANJI Y, EL-MARAGHY SA, TAHA MO, AL GHUSSEIN MA S 2013 Naproxen and cromolyn as new glycogen synthase kinase $3 \beta$ inhibitors for amelioration of diabetes and obesity: an investigation by docking simulation and subsequent in vitro/in vivo biochemical evaluation. J Biochem Mol Toxicol 27: 425-436. https://doi.org/10.1002/jbt.21503

179. WILLIAMSON RT 1901 On the treatment of glycosuria and diabetes mellitus with sodium salicylate. Br Med J 1: 760-762. https://doi.org/10.1136/bmj.1.2100.760

180. SMITH MJ, MEADE BW 1952 The effect of salicylate on glycosuria, blood glucose and liver glycogen of the alloxan-diabetic rat. Biochem J 51: 18-20. https://doi.org/10.1042/bj0510018 
181. SMITH MJ 1952 The effect of salicylate on the glycosuria and hyperglycaemia induced by cortisone in the normal rat. Biochem J 52: 649-652. https://doi.org/10.1042/bj0520649

182. SPROULL DH 1954 The glycogenolytic action of sodium salicylate. Br J Pharmacol Chemother 9: 121-124. https://doi.org/10.1111/j.1476-5381.1954.tb00828.x

183. SMITH MJ 1955 The effects of sodium salicylate on blood glucose in the rat. Br J Pharmacol Chemother 10: 110-112. https://doi.org/10.1111/j.1476-5381.1955.tb00067.x

184. MORGAN HE, RANDLE PJ, REGEN DM 1959 Regulation of glucose uptake by muscle. 3 . The effects of insulin, anoxia, salicylate and 2:4-dinitrophenol on membrane transport and intracellular phosphorylation of glucose in the isolated rat heart. Biochem J 73: 573-579. https://doi.org/10.1042/bj0730573

185. FIELD JB, BOYLE C, REMER A 1967 Effect of salicylate infusion on plasma-insulin and glucose tolerance in healthy persons and mild diabetics. Lancet 1: 1191-1194. https://doi.org/10.1016/s0140-6736(67)92842-5

186. KIM JK, KIM YJ, FILLMORE JJ, CHEN Y, MOORE I, LEE J, YUAN M, LI Z W, KARIN M, PERRET P, SHOELSON SE, SHULMAN GI 2001 Prevention of fat-induced insulin resistance by salicylate. J Clin Investigation 108: 437-446. https://doi.org/10.1172/JCI11559

187. GOLDFINE AB, FONSECA V, JABLONSKI KA, CHEN YD, TIPTON L, STATEN MA, SHOELSON SE 2013 Salicylate (salsalate) in patients with type 2 diabetes: a randomized trial. Ann Intern Med 159: 1-12. https://doi.org/10.7326/0003-4819-159-1-201307020-00003

188. SERIZAWA Y, OSHIMA R, YOSHIDA M, SAKON I, KITANI K, GOTO A, TSUDA S, HAYASHI T 2014 Salicylate acutely stimulates 5'-AMP-activated protein kinase and insulin-independent glucose transport in rat skeletal muscles. Biochem Biophys Res Commun 453: 81-85.

https://doi.org/10.1016/j.bbrc.2014.09.066

189. ABOUZED TK, MUNESUE S, HARASHIMA A, MASUO Y, KATO Y, KHAILO K, YAMAMOTO H, YAMAMOTO Y 2016 Preventive effect of salicylate and pyridoxamine on diabetic nephropathy. J Diabetes Res 2016: 1786789. https://doi.org/10.1155/2016/1786789

190. REID J, MACDOUGALL AI, ANDREWS MM 1957 Aspirin and diabetes mellitus. Br Med J 2: 1071-1074. https://doi.org/10.1136/bmj.2.5053.1071

191. MICOSSI P, PONTIROLI AE, BARON SH, TAMAYO RC, LENGEL F, BEVILACQUA M, RAGGI U, NORBIATO G, FOÀ PP 1978 Aspirin stimulates insulin and glucagon secretion and increases glucose tolerance in normal and diabetic subjects. Diabetes 27: 1196-1204. https://doi.org/10.2337/diab.27.12.1196

192. EL MIDAOUI A, WU R, DE CHAMPLAIN J 2002 Prevention of hypertension, hyperglycemia and vascular oxidative stress by aspirin treatment in chronically glucose-fed rats. J Hypertens 20 : 1407-1412. https://doi.org/10.1097/00004872-200207000-00028
193. CARVALHO-FILHO MA, ROPELLE ER, PAULI RJ, CINTRA DE, TSUKUMO DML, SILVEIRA LR, CURI R, CARVALHEIRA JBC, VELLOSO LA, SAAD MJA 2009 Aspirin attenuates insulin resistance in muscle of diet-induced obese rats by inhibiting inducible nitric oxide synthase production and Snitrosylation of IRbeta/IRS-1 and Akt. Diabetologia 52: 24252434. https://doi.org/10.1007/s00125-009-1498-1

194. THORNTON CC, AL-RASHED F, CALAY D, BIRDSEY GM, BAUER A, MYLROIE H, MORLEY BJ, RANDI AM, HASKARD DO, BOYLE JJ, MASON JC 2016 Methotrexatemediated activation of an AMPK-CREB-dependent pathway: a novel mechanism for vascular protection in chronic systemic inflammation. Ann Rheum Dis 75: 439-448. https://doi.org/10.1136/annrheumdis-2014-206305

195. CRONSTEIN BN 2005 Low-dose methotrexate: a mainstay in the treatment of rheumatoid arthritis. Pharmacol Rev 57: 163172. https://doi.org/10.1124/pr.57.2.3

196. SOLOMON DH, GLYNN RJ, KARLSON EW, LU F, CORRIGAN C, COLLS J, XU C, MACFADYEN J, BARBHAIYA M, BERLINER N, DELLARIPA PF, EVERETT BM, PRADHAN AD, HAMMOND SP, MURRAY M, RAO DA, RITTER SY, RUTHERFORD A, SPARKS JA, STRATTON J, SUH DH, TEDESCHI SK, VANNI KMM, PAYNTER NP, RIDKER PM 2020 Adverse effects of low-dose methotrexate: a randomized trial. Ann Intern Med 172: 369-380. https://doi.org/10.7326/M19-3369

197. SHIROKY JB, NEVILLE C, ESDAILE JM, CHOQUETTE D, ZUMMER M, HAZELTINE M, BYKERK V, KANJI M, STPIERRE A, ROBIDOUX L, BOURQUE L 1993 Low-dose methotrexate with leucovorin (folinic acid) in the management of rheumatoid arthritis. Results of a multicenter randomized, double-blind, placebo-controlled trial. Arthritis Rheum 36: 795-803. https://doi.org/10.1002/art.1780360609

198. TISHLER M, CASPI D, FISHEL B, YARON M 1988 The effects of leucovorin (folinic acid) on methotrexate therapy in rheumatoid arthritis patients. Arthritis Rheum 31: 906-908. https://doi.org/10.1002/art.1780310712

199. GALIC S, FULLERTON MD, SCHERTZER JD, SIKKEMA $S$, MARCINKO K, WALKLEY CR, IZON D, HONEYMAN J, CHEN ZP, VAN DENDEREN BJ, KEMP BE, STEINBERG GR 2011 Hematopoietic AMPK beta1 reduces mouse adipose tissue macrophage inflammation and insulin resistance in obesity. J Clin Invest 121: 4903-4915. https://doi.org/10.1172/JCI58577

200. MOUNIER R, THERET M, ARNOLD L, CUVELLIER S, BULTOT L, GORANSSON O, SANZ N, FERRY A, SAKAMOTO K, FORETZ M, VIOLLET B, CHAZAUD B 2013 AMPKalpha1 regulates macrophage skewing at the time of resolution of inflammation during skeletal muscle regeneration. Cell Metab 18: 251-264. https://doi.org/10.1016/j.cmet.2013.06.017

201. DONATH MY, SHOELSON SE 2011 Type 2 diabetes as an inflammatory disease. Nat Rev Immunol 11: 98-107. https://doi.org/10.1038/nri2925 